\title{
Forecasting in dynamic factor models subject to structural instability
}

\section{Citation}

Stock, James, and Mark Watson. 2009. Forecasting in dynamic factor models subject to structural instability. In The Methodology and Practice of Econometrics: A Festschrift in Honour of David F. Hendry, edited by Jennifer Castle and Neil Shepard. Oxford: Oxford University Press.

\section{Published Version}

10.1093/acprof:oso/9780199237197.003.0007

\section{Permanent link}

http://nrs.harvard.edu/urn-3:HUL.InstRepos:33200489

\section{Terms of Use}

This article was downloaded from Harvard University's DASH repository, and is made available under the terms and conditions applicable to Other Posted Material, as set forth at http:// nrs.harvard.edu/urn-3:HUL.InstRepos:dash.current.terms-of-use\#LAA

\section{Share Your Story}

The Harvard community has made this article openly available.

Please share how this access benefits you. Submit a story.

Accessibility 
The Methodology and Practice of Econometrics: A Festschrift in Honour of David F. Hendry

Jennifer Castle and Neil Shephard

Print publication date: 2009

Print ISBN-13: 9780199237197

Published to Oxford Scholarship Online: Sep-09

DOI: 10.1093/acprof:oso/9780199237197.001.0001

Forecasting in Dynamic Factor Models Subject to Structural Instability*

James H. Stock, Mark W. Watson

DOI: 10.1093/acprof:0so/9780199237197.003.0007

\section{Abstract and Keywords}

This chapter assesses forecasts constructed using dynamic factor models for their reliability in the face of structural breaks. Dynamic factor models have had notable empirical forecasting successes, but there has been little work to date on the performance of factor-based macroeconomic forecasts under structural instability. In factor models, even if factor loadings are unstable, if the instability is sufficiently independent across series then the estimated factors could be well estimated even if individual relations between the observable series and the factors are unstable. This chapter first lays out the implications for forecasting of different types of structural instability in dynamic factor models, provides a new empirical investigation (using US data for 144 quarterly macroeconomic time series) of factor-based forecasting with potential instability, and investigates separately the effects of structural change on the estimation of the factors and on the use of those factors for forecasting.

Keywords: dynamic factor models, structural breaks, instability, time-varying factor models, factor loadings

\subsection{Introduction}

An ongoing theme in David Hendry's work has been concern about detecting and avoiding forecast breakdowns that arise because of structural instability. Parameter instability can arise for various reasons, including structural breaks in the economy (for example, changes in technology), policy 
regime shifts, or changes in the survey instruments from which the timeseries are constructed. Hendry and coauthors have argued that such instability, whatever its source, often manifests itself as breaks in timeseries forecasting relations, and moreover that such breaks constitute one of the primary reasons for forecast failures in practice (see for example Clements and Hendry, 1999, 2002; Hendry and Clements, 2002; Hendry, 2005; and Hendry and Mizon, 2005). One line of Hendry's research has been to develop and to analyse non-structural forecasting methods for their potential robustness to parameter instability, including error correction models, overdifferencing, intercept shift methods, and-closest to the focus of this chapter-forecast pooling (Hendry and Clements, 2002).

This chapter continues this line of inquiry, in which forecasting methods are examined for their reliability in the face of structural breaks. We focus here on forecasts constructed using dynamic factor models (DFMs) (Geweke, 1977; Sargent and Sims, 1977). In DFMs, the comovements of the observable time-series are characterized by latent dynamic factors. Over the past decade, work on DFMs has focused on high-dimensional systems in which very many series depend on a handful of factors (Forni, Lippi, Hallin, and Reichlin, 2000; Stock and Watson, 2002a, 2002b; and many others; for a survey, see Stock and Watson, 2006). These factor-based forecasts have had notable (p. 174 ) empirical forecasting successes. Yet, there has been little work to date on the performance of factor-based macroeconomic forecasts under structural instability (exceptions are Stock and Watson, 1998, 2002b and Banerjee, Marcellino, and Masten, 2007, which are discussed below).

Despite the limited research on the effect of structural instability on forecasting using factor models, it is plausible that factor-based forecasts might be robust to certain types of structural instability, for reasons akin to those discussed in Hendry and Clements (2002) in the context of forecast pooling. Hendry and Clements (2002) consider forecast breakdowns arising from intercept shifts, which in turn arise from shifts in the means of omitted variables. These intercept breaks doom the forecasting regression in which they arise, but if one averages forecasts over many forecasting regressions, and if the intercept shifts are sufficiently uncorrelated across the different regressions, then the intercept shifts average out and the pooled forecast is relatively more robust to this source of structural instability than any of the constituent forecasting regressions. In factor models, a similar logic could apply: even if factor loadings are unstable, if the instability is sufficiently independent across series then using many series to estimate the factors could play the same 'averaging' role as the pooling of forecasts, 
and the estimated factors could be well estimated even if individual relations between the observable series and the factors are unstable. Given well-estimated factors, forecasts can be made by standard time-varying parameter or rolling regression methods.

This chapter provides empirical results concerning the estimation of dynamic factors and their use for forecasting when there is structural instability in the underlying factor model. Section 7.2 lays out the time-varying DFM and categorizes the implications for forecasting when the model is subject to different types of structural instability (breaks in the factor loadings, in the factor dynamics, or in the idiosyncratic dynamics). Section 7.2 also reviews what little is known about factor estimation and forecasting with structural instabilities.

We then turn to an empirical examination of instability in DFMs using a new data set consisting of 144 quarterly macroeconomic time-series for the United States, spanning 1959-2006. This data set, which is described in section 7.3, improves upon earlier versions of the Stock-Watson US quarterly data set by having more complete and consistent tiers of disaggregation. Motivated by the literature on the Great Moderation, we consider splitsample instability with a single break in 1984. Our forecast comparisons focus on the performance of different ways of handling this break, relative to standard full-sample factor-based forecasts (there have been numerous studies comparing full-sample factor-based forecasts to other forecasting methods and we do not repeat those exercises here, see Stock and Watson (2006) for a review). The results are summarized in section 7.4. We find considerable instability in the factor loadings around the 1984 break date, but despite this (p. 175 ) instability principal components provides stable estimates of the factors. In consequence, the best factor-based forecasts of individual variables use full- sample estimates of the factors but use subsample (or time-varying) estimates of the regression coefficients.

The chapter most closely related to this are Stock and Watson (1998, 2002b), Banerjee, Marcellino, and Masten (2007), and Del Negro and Otrok (2008). Stock and Watson (2002b) provide some theoretical results concerning factor estimation (but not forecasting) with time variation. Stock and Watson (1998) and Banerjee, Marcellino, and Masten (2007) provide Monte Carlo results about, respectively, nonparametric principle components estimation of factors and factor-based forecasting with instability. Banerjee, Marcellino, and Masten (2007) also report an application to data from the EU and from Slovenia, which investigates split-sample instability in the factor 
forecasts (but not the factor estimates themselves). Del Negro and Otrok (2008) investigate a parametric DFM estimated on G-7 data using Bayer methods. Relative to these papers, the contribution here is first to lay out the implications for forecasting of different types of structural instability in DFMs, second to provide a new empirical investigation using US data of factor-based forecasting with potential instability, and third to investigate separately the effects of structural change on the estimation of the factors and on the use of those factors for forecasting. An additional contribution is the compilation of the new quarterly data set, which is available on Watson's website.

\subsection{The Time-Varying Dynamic Factor Model and Implications for Factor-Based Forecasts}

This section sets out the time-varying dynamic factor model and examines the separate implications for forecasting of structural breaks in the factor loadings, in the factor dynamics, and in the idiosyncratic dynamics.

\subsubsection{The Time-Varying Factor Model}

We work with the static representation of the dynamic factor model $X_{t}=\Lambda_{t} F_{t}+e_{t}$

where $X_{t}=\left(X_{1 t}, \ldots, X_{n t}\right)^{\prime}, F_{t}$ is a $r$-vector of static factors, $\Lambda_{t}$ is a $n$ $\times r$ matrix of factor loadings, and $e_{t}=\left(e_{1 t}, \ldots, e_{n t}\right)^{\prime}$ is a $n$-vector of idiosyncratic disturbances. The difference between (7.1) and standard formulations of the DFM is that (7.1) allows for the possibility that the factor loadings can change over time.

Although parametric specifications for the factor and idiosyncratic dynamics are not needed to estimate the factors, such parametric specifications are (p. 176 ) useful when discussing forecasts using the factors. Accordingly, we specify finite-order autoregressive dynamics for the factors and idiosyncratic term

$F_{t}=\Phi_{t} F_{t-1}+\eta_{t}$

(7.2)

$e_{i t}=a_{i t}(L) e_{i t-1}+\epsilon_{i t}, i=1, \ldots, n$,

(7.3) 
where $\eta_{t}$ is a $r$-vector of factor innovations with $\mathrm{E}\left(\eta_{t} \mid F_{t-1}, F_{t-2}, \ldots, X_{i t-1}\right.$, $X i t-2, \ldots)=0$. The static factor model (7.1)-(7.3) can be derived from the dynamic factor model assuming finite lag lengths and VAR factor dynamics in the dynamic factor model, in which case $F{ }_{t}$ contains lags of the dynamic factors and $\Phi_{t}$ it is a companion matrix so that the static factor dynamics are first order.

\subsubsection{Time-Varying Forecast Functions with Split-Sample Time Variation}

For the discussion in this subsection, suppose that $E\left(\varepsilon_{\text {is }} \mid F_{t}, F_{t-1}, \ldots, X_{\text {it }}\right.$, $\left.X_{i t-1}, \ldots\right)=0$ and $E\left(\eta_{s} \mid F_{t}, F_{t-1}, \ldots, X_{i t}, X_{i t-1}, \ldots\right)=0$ for $\mathrm{s}>\mathrm{t}$, and that the idiosyncratic errors $\left\{\eta_{i t}\right\}$ are uncorrelated with the factor disturbances $\left\{\eta_{t}\right\}$ at all leads and lags. Then, given the data and factors through date $t$, and assuming the potentially time varying parameters are known, the $h$-step ahead conditional expectation of $X i t+h$ is

$$
\begin{gathered}
X_{i t+h \mid t}=E\left(X_{i t+h} \mid F_{t}, F_{t-1, .}, X_{i t}, X_{i t-1}, \ldots\right) \\
=E\left(\Lambda_{t+h} F_{t+h}+e_{t+h} \mid F_{t}, F_{t-1}, \ldots, X_{i t,} X_{i t-1}, \ldots\right) \\
=\beta_{i t}^{h^{\prime}} F_{t}+a_{i t}^{h}(L) e_{i t},
\end{gathered}
$$

where

$\beta_{i t}^{h^{\prime}}=\Lambda_{i t+h} \prod_{s=t+1}^{t+h} \Phi_{s}$

and

$a_{i t}^{h}(L) e_{i t}^{\prime}=E\left[a_{i t+h}(L) e_{t+h-1} \mid F_{t}, F_{t-1}, \ldots, X_{i t}, X_{i t-1}, \ldots\right]=E\left[e_{i t+h} \mid e_{i t}, e_{i t-1}, \ldots\right]$,

where the final equality obtains by using the factor model assumption that $\left\{e_{i t}\right\}$ and $\left\{\eta_{t}\right\}$ are independent and by modelling expectations as linear.

Looking ahead to the empirical analysis, we consider the case of a single break at known date $t=\tau$, and consider three special cases of interest, respectively corresponding to a break in $\Lambda, \Phi$, and $a$ it $(\mathrm{L})$.

(a) Forecast function with a single break in $\Lambda$. In this case, $\Lambda_{\text {it }}$ $=\Lambda_{i 1}, t<\tau$, and $\Lambda_{i t}=\Lambda_{i 2}, t \geq \tau$, so (7.4) becomes

$X_{i t+h t t}=\left\{\begin{array}{c}\beta_{i 1}^{h^{\prime}} F_{t}+a_{i}^{h}(L) e_{i t}, t<\tau-h, \mathrm{w} \text { h e r e } \beta_{i 1}^{h^{\prime}}=\Lambda_{i 1} \phi^{h} \\ \beta_{i 2}^{h^{\prime}} F_{t}+a_{i}^{h}(L) e_{i t}, t \geq \tau, \mathrm{w} \text { h e r e } \beta_{i 2}^{h^{\prime}}=\Lambda_{i 2} \Phi^{h}\end{array}\right.$ 
If the only break is in the factor loadings, then coefficients on $F t_{t}$, but not those on $e$ it and its lags, change.

(p. 177 )

(b) Forecast function when only $\Phi$ is time-varying . In this case, $\Phi_{t}=\Phi_{1}, t<\tau$, and $\Phi_{t}=\Phi_{2}, t \geq \tau$, so (7.4) becomes

$X_{i t+h l t}=\left\{\begin{array}{l}\beta_{i 1}^{h^{\prime}} F_{t}+a_{i}^{h}(L) e_{i t}, t<\tau-h, \mathrm{w} \text { h e r e } \beta_{i 1}^{h^{\prime}}=\Lambda_{i} \Phi_{1}^{h} \\ \beta_{i 2}^{h^{\prime}} F_{t}+a_{i}^{h(L)} e_{i t}, t \geq T, \mathrm{w} \text { h e r e } \beta_{i 2}^{h^{\prime}}=\Lambda_{i} \Phi_{2}^{h}\end{array}\right.$

If the only break is in the factor dynamics, then only the coefficients on $F$ t change.

( c ) Forecast function when only a it is time-varying .

In this case, $a{ }_{i t}(\mathrm{~L})=a{ }_{i 1}(\mathrm{~L}), t<\tau$, and $a{ }_{i t}(\mathrm{~L})=a_{i 2}(\mathrm{~L}), t \geq \tau$, so (7.4) becomes

$X_{i t+h l t}=\left\{\begin{array}{c}\beta_{i}^{h^{\prime}} F_{t}+a_{i 1}^{h}(L) e_{i t}, t<T-h \\ \beta_{i}^{h^{\prime}} F_{t}+a_{i 2}^{h}(L) e_{i t}, t \geq T\end{array}\right.$

where

$\beta_{i}^{h^{\prime}}=\Lambda_{i} \phi^{h}$

. If the only break is in the idiosyncratic dynamics, then only coefficients on $e$ it and its lags change.

In certain circumstances these expressions can tell a researcher what sort of forecast instability to expect. For example, a revision of the survey used to construct a particular series $X$ it generally would result in different dynamics for the idiosyncratic term (case (c)) and possibly a change in the factor loadings (case (a)), but not a change in the factor dynamics. Although the origin of the instability is not in general known a priori, by working backwards, these three cases can help to identify the nature of an observed structural break. Stable factor loadings in (7.1), combined with a break in the coefficient on $F_{t}$ in (7.4), point to a break in the factor dynamics. Similarly, a break in the coefficients on lagged $e_{i t}$ in (7.4) points to a break in the idiosyncratic dynamics. 


\subsubsection{Estimation of Static Factors in the Presence of Time Variation}

The only theoretical result concerning factor estimation under model instability of which we are aware is Stock and Watson (2002b), theorem 3 . That result states that the factor space can be consistently estimated if there is time variation in the factor loadings, as long as that time variation is relatively small in magnitude. Monte Carlo results in Stock and Watson (1998) support this theoretical result, in fact even with quite large time variation in the factor loadings the Stock-Watson (1998) Monte Carlo experiments suggest that the factors are well estimated using principal components. That paper does not, however, consider time variation in the factor transition equation itself $\left(\Phi_{t}\right)$.

As the cases considered in section 7.2.2 make clear, robust estimation of the factors under time variation does not imply that factor-based forecasts will be robust to time variation because of implied instability in the forecast function. This deterioration of factor-based forecasts (in contrast to the estimation of the factors themselves) is evident in Banerjee, Marcellino, and Masten's (2007) (p. 178 ) Monte Carlo results. This dichotomy-potential stability of factor estimates but instability of factor-based forecasts-is the main focus of the empirical application in section 7.4.

\subsection{The Quarterly US Data Set}

The empirical work employs a newly compiled data set consisting of 144 quarterly time series for the United States, spanning 1959:I-2006:IV. The variables, sources, and transformations are listed in Appendix Table A.1. The first two quarters were used for initial values when computing first and second differences, so the data available for analysis span 1959:III-2006:IV, for a total of $T=190$ quarterly observations.

The main change in the new data set, relative to the quarterly data sets we have used in previous work, is a more complete treatment of disaggregation. The full data set contains both aggregate and subaggregate series. By construction, the idiosyncratic term of aggregate series (eg nonresidential investment) will be correlated with the idiosyncratic term of lower-level subaggregates (eg nonresidential investment-structures), and the inclusion of series related by identities (an aggregate being the sum of the subaggregates) does not provide additional information useful for factor estimation. For this reason, the factor estimates were computed using the subset of 109 series that excludes higher level aggregates related by 
identities to the lower level subaggregates (the series used to estimate the factors are indicated in Table A.1). This represents a departure from the approach in some previous work (e.g. Stock and Watson, 2002a, 2005) in which both aggregates and subaggregates are used to estimate the factors. The data set here includes more subaggregates than the quarterly data set in Stock and Watson (2005).

The series were transformed as needed to eliminate trends by first or second differencing (in many cases after taking logarithms); see Table A.1 for specifics.

\subsection{Empirical Results}

The empirical analysis focuses on instability around a single break in 1984:I. The reason for the 1984 break date is that 1984 (more generally, the mid1980s) has been identified as an important break date associated with the so-called Great Moderation of output (Kim and Nelson, 1999; McConnell and Perez-Quiros, 2000), and there have been shifts in other properties of timeseries such as the inflation-output relation that can be dated to the mid- to late-1980s (cf. Stock and Watson, 2007).

Our analysis of forecasting stability focuses on four-quarter ahead prediction. For real activity variables, the four-quarter object of interest, $X_{i t+4}^{(4)}$

(p. 179 ) corresponds to growth over the next four quarters; for inflation measures, $X_{i t+4}^{(4)}$

is average quarterly inflation over the next four quarters, minus inflation last quarter; and for variables entered in levels such as the capacity utilization rate, it is the value of that variable four quarters hence. Specifics are given in the appendix.

All forecasts are direct, specifically, forecasts of

$X_{i t+4}^{(4)}$

are obtained by regressing

$X_{i t+4}^{(4)}$

on variables dated $t$ and earlier using the forecasting regression, $X_{i t+4}^{(4)}=\mu_{i}+\beta_{i}^{\prime} \hat{F}_{t}+\sum_{j=0}^{p-1} a_{i j}^{4} \hat{e}_{i t-j}+$ e r r o r. 
For comparability of results across series, $p=4$ lags of $\hat{e}_{i t}$ were used for all forecasts.

\subsubsection{The Number and Stability of the Factors}

Estimates of the number of factors. Table 7.1 presents estimates of the number of factors, computed using criteria proposed by Bai and $\mathrm{Ng}$ (2002), for the full sample and the two subsamples. The results are not sharp and depend on which criterion is used. For the purposes of forecasting, 10 factors (the ICP3 estimate) introduces a large number of parameters in the forecasting regressions so we focus on numbers of factors towards the lower end of the range in Table 7.1, three to five factors.

\section{Comparison of full-sample and subsample estimated factors .}

Theorem 3 in Stock and Watson (2002b) suggests that, despite possible time variation in the factor loadings, full- and subsample estimates of the factors could well be close, in the sense that the subsample estimates of the factor space is nearly spanned by the full-sample estimate of the factor space. This possibility is examined in Table 7.2, which presents the squared canonical correlations, computed over the two subsamples, between the factors estimated over the full sample and the factors estimated over the subsample. The factors were estimated by principal components over the full sample or subsample as appropriate, always using the 109 variable data set of subaggregates indicated

Table 7.1. Number of factors estimated using Bai-Ng (2002) criteria

\begin{tabular}{|c|c|c|c|c|c|}
\hline \multirow[t]{2}{*}{ Sample } & \multirow[t]{2}{*}{ Dates } & \multirow[t]{2}{*}{ No. Obs } & \multicolumn{3}{|c|}{ Estimated number of factors based on: } \\
\hline & & & ICP1 & ICP2 & ICP3 \\
\hline Full & $\begin{array}{l}\text { 1959:III- } \\
2006: I V\end{array}$ & 190 & 4 & 2 & 10 \\
\hline Pre-84 & $\begin{array}{c}\text { 1959:III- } \\
\text { 1983:IV }\end{array}$ & 98 & 3 & 2 & 10 \\
\hline Post-84 & $\begin{array}{l}\text { 1984:I- } \\
2006: I V\end{array}$ & 92 & 3 & 2 & 10 \\
\hline
\end{tabular}

Note: All estimates use $N=109$ series.

(p. 180 ) 
Table 7.2. Canonical correlations between subsample and full-sample estimates of the factors

\section{Estimated Squared canonical correlations between full- and subsample number of factors: \\ factors}

Full Subsaniples 84

Post-84

sample

$\begin{array}{llllllllllll} & & \mathbf{1} & \mathbf{2} & \mathbf{3} & \mathbf{4} & \mathbf{5} & \mathbf{1} & \mathbf{2} & \mathbf{3} & \mathbf{4} & \mathbf{5} \\ 3 & 3 & 1.00 & 0.99 & 0.03 & & & 0.99 & 0.91 & 0.84 & & \\ 4 & 3 & 1.00 & 0.99 & 0.92 & & & 0.99 & 0.92 & 0.91 & & \\ 4 & 4 & 1.00 & 0.99 & 0.94 & 0.33 & & 1.00 & 0.93 & 0.92 & 0.65 & \\ 5 & 4 & 1.00 & 0.99 & 0.94 & 0.89 & & 1.00 & 0.97 & 0.92 & 0.74 & \\ 5 & 5 & 1.00 & 1.00 & 0.94 & 0.90 & 0.49 & 1.00 & 0.97 & 0.93 & 0.79 & 0.11\end{array}$

Notes: The entries are the squared canonical correlations between the estimated factors in the indicated subsam- ple and the factors estimated over the full-sample. Factors are estimated using principal components.

in the Appendix. Canonical correlations close to one indicate that the fullsample and subsample factors span nearly the same spaces.

The results in Table 7.2 are consistent with there being four full-sample factors and three or four factors in each subsample. If there were only two full- and subsample factors (as suggested by the ICP2 results in Table 7.1), then one would expect the third and fourth estimated factors to have little relation to each other over the two subsamples (they would be noise), so the third canonical correlation would be low in both samples. But this is not the case, suggesting that there are at least three factors in each subsample. When four factors are estimated in both the full sample and the subsamples, the fourth canonical correlation is small in the first subsample; this is consistent with the space of three first subsample factors being spanned by the four full- sample factors, and the fourth subsample factor being noise. The moderate fourth canonical correlation in the second subsample in the case of four full- and four subsample factors leads to some ambiguity, and raises the possibility that there are four factors in the second subsample, which in turn would be consistent with four factors in the full sample. 
We interpret the results in Tables 7.1 and 7.2 , taken together, as being consistent with there being four factors in the full sample and three factors in each subsample. The large squared canonical correlations in Table 7.2 for four full-sample and three subsample factors indicate that the full-sample estimated factors span the space of the three estimated factors in each subsample. Accordingly, the base case for our empirical analysis (the case used to compute all subsequent tables and figures) has four full-sample factors and three subsample factors. Still, the statistics in Table 7.2 alternatively could be interpreted as being consistent with other numbers of factors in the full sample and subsamples. As a robustness check, results therefore were also computed for 4 full/4 subsample, 5 full/4 subsample, and 5 full/ 5 subsample factors; these results are discussed briefly at the end of this section.

\section{(p. 181 ) 7.4.2 Stability of Factor Loadings and Forecasting Regression Coefficients}

Stability of factor loadings. The stability of the factor loadings are examined in the first numeric column Table 7.3, which reports Chow statistics testing the hypothesis that the factor loadings are the same in the two subsamples, computed by regressing each variable onto the four full-sample estimated factors, allowing for a break in 1984:1 and using the NeweyWest (1987) variance estimator (four lags). There is evidence of some instability in the factor loadings: $41 \%$ of these Chow statistics reject at the $5 \%$ significance level, and $23 \%$ reject at the $1 \%$ significance level. If one compares the results across classes of series, there are relatively fewer rejections of the stability of the factor loadings for output, employment, and inflation, and relatively more for exchange rates, term spreads, and stock returns.

Figures 7.1-7.4 focus on the stability of the estimated factors and the factor loadings for four series: real GDP growth, temporally aggregated to be the four-quarter average of the quarterly growth rates (Figure 7.1); the change in core PCE inflation, temporally aggregated to be the four-quarter change in inflation (Figure 7.2); the quarterly change in the Federal Funds rate (not temporally aggregated, Figure 7.3); and the term spread between the one-year and 3-month Treasury rates (not temporally aggregated, Figure 7.4). Part (a) of each figure presents the series, the common component computed using factors estimated from the full sample with split-sample estimates of the factor loadings (the 'full-split' estimate), and the common component computed using split-sample estimates of the factors and split- 
sample estimates of the factor loadings ('split-split'). Part (b) presents the series, the full-split estimate of the common component, and the common component computed using factors estimated from the full sample and fullsample estimates of the factor loadings ('full-full').

In all four figures, the full-split and split-split common components (part (a)) are quite similar, consistent with the full-sample factor estimates spanning the spaces of the subsample factor estimates. There are, however, two different patterns evident in part (b) of the figures. For GDP, core PCE, and the Federal Funds rate, the full-split and full-full are similar, indicating that for those series there is little time variation in the factor loadings. This is consistent with the failure of the Chow statistic to reject the hypothesis of stable $\Lambda$ 's for those three series in Table 7.3. In contrast, stability of the factor loadings is rejected at the $1 \%$ significance level for the term spread, and the common components computed using the full-sample factors differ greatly depending on whether the factor loadings are estimated over the full sample or the subsample. 

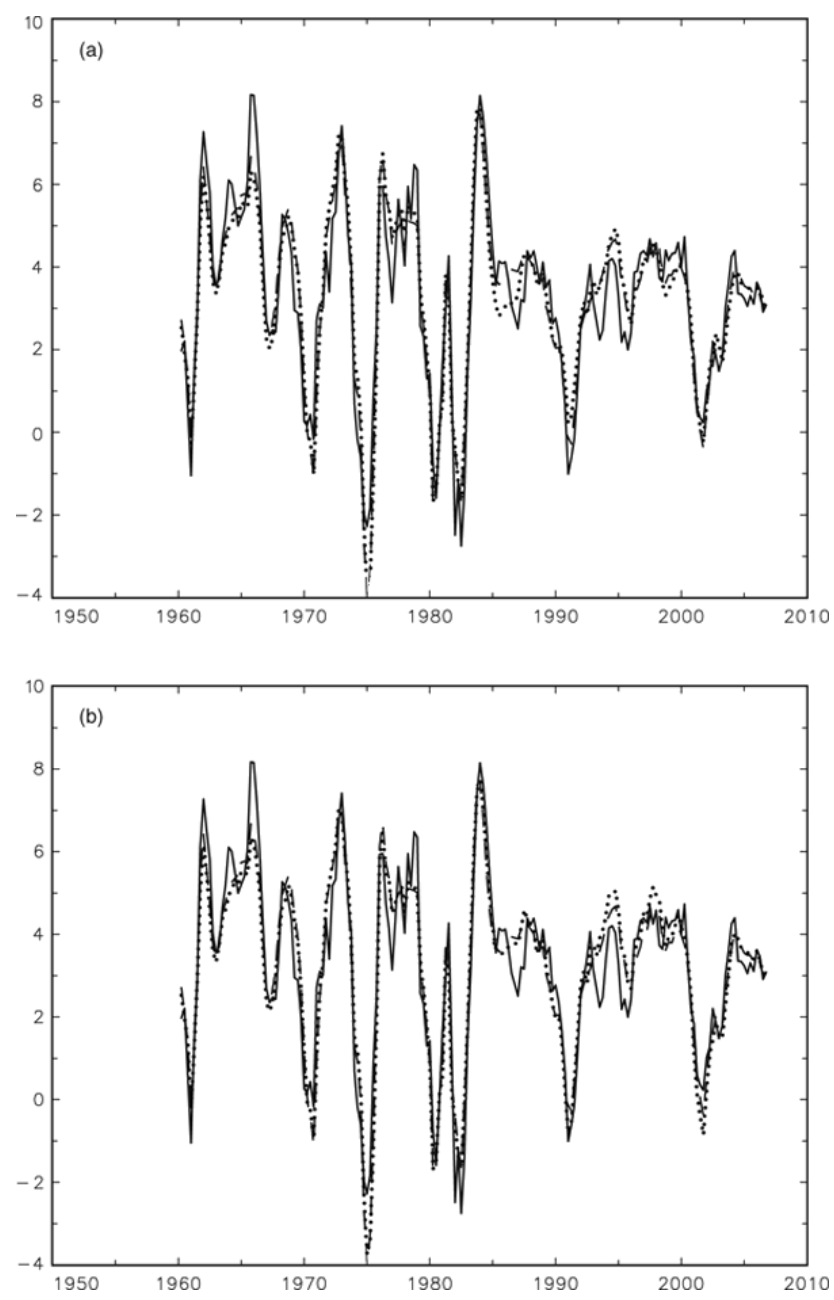

Fig. 7.2. Four-quarter change in core PCE inflation (solid line) and three estimates of its common component.

(a) full-split (dashes) and split-split (dots)

(b) full-split (dashes) and full-full (dots) 

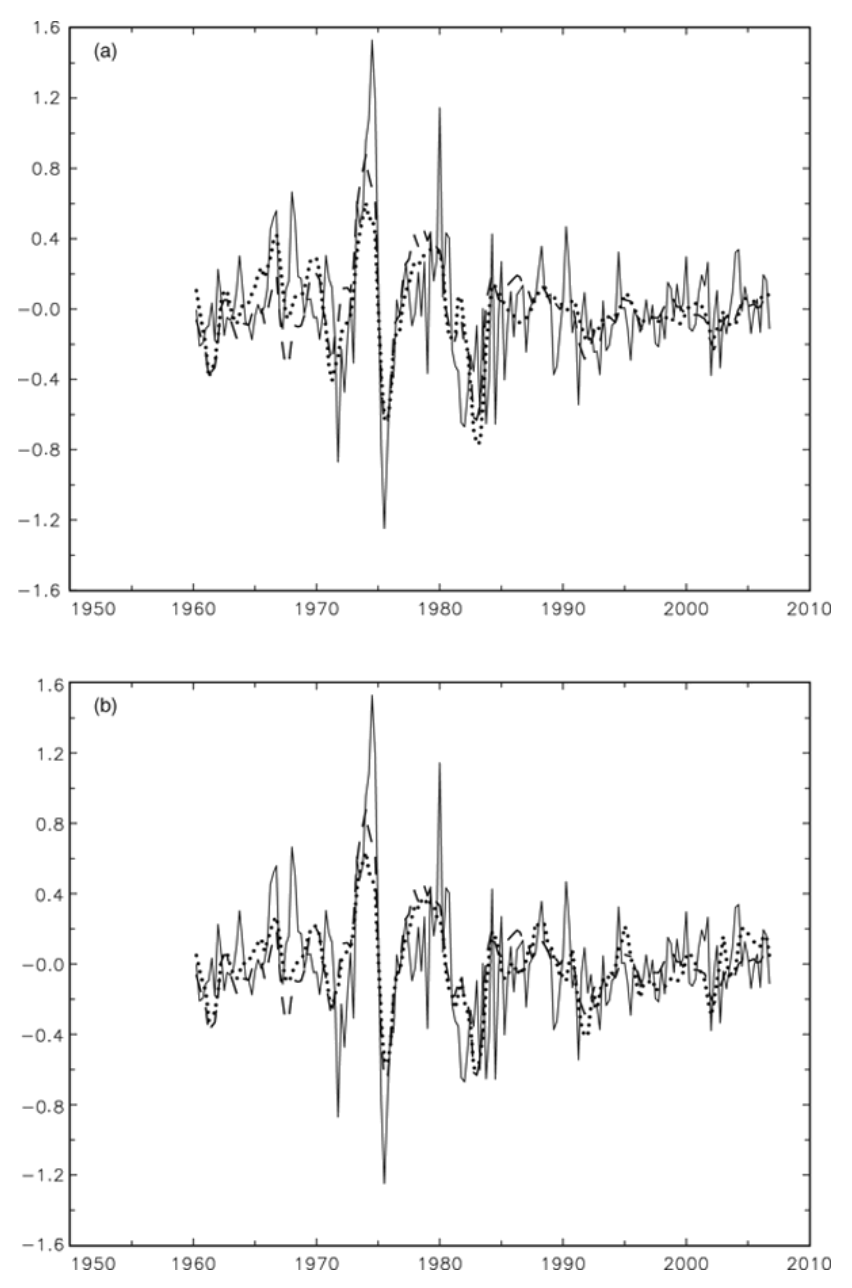

Fig. 7.3. The Federal Funds rate (solid line) and three estimates of its common component.

(a) full-split (dashes) and split-split (dots)

(b) full-split (dashes) and full-full (dots) 

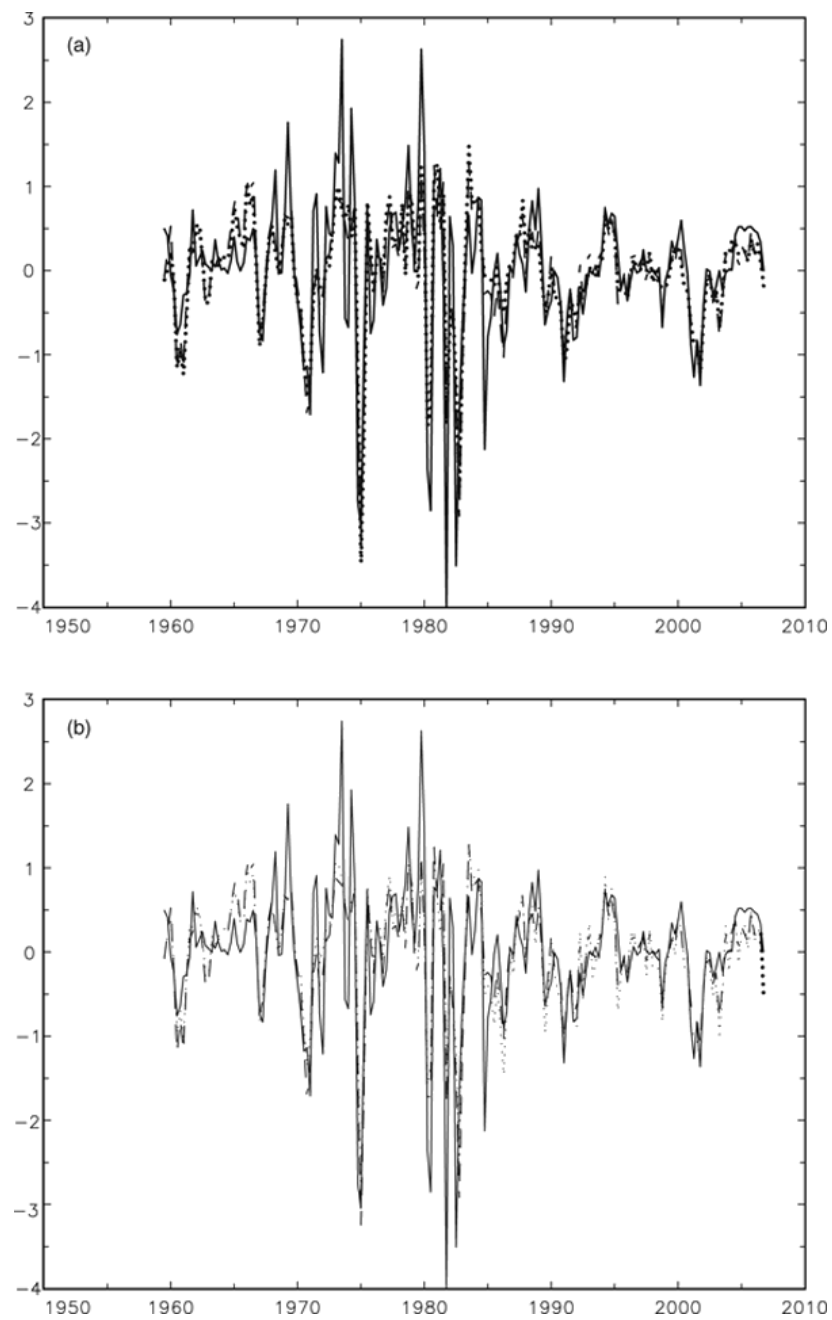

Fig. 7.4. The one-year/3-month Treasury term spread (solid line) and three estimates of its common component.

(a) full-split (dashes) and split-split (dots)

(b) full-split (dashes) and full-full (dots) 

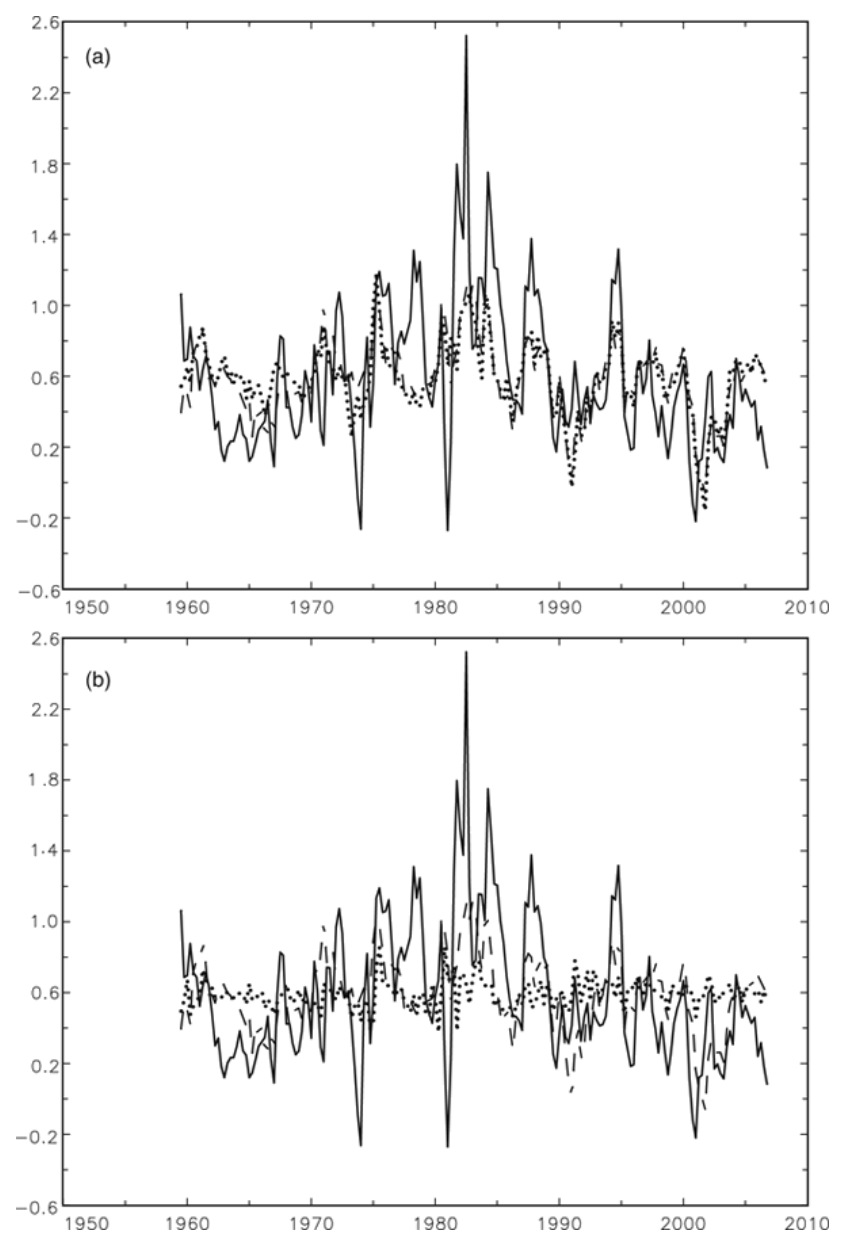

Fig. 7.5(a). Histogram of relative MSEs of full-split forecasts to full-full forecasts, pre- 1984 sample $($ mean $=0.91$, median $=0.92$ ).

Stability of forecasting regressions. The remaining numeric columns of Table 7.3 examine the stability of the coefficients in the forecasting regression (7.8). Specifically, (7.8) was estimated by OLS using 4 lags ( $p=4$ in (7.8)), where $\hat{e}_{i t}$ in (7.8) was computed as the residual from the regression of $X$ it onto (p. 182 )

Table 7.3. Chow statistics testing the stability of the factor loadings and the 4-step ahead forecasting equations, 4-factor model

Factor loading null regression:

$X_{i t}=\Lambda_{i}^{\prime} \hat{F}_{t}+e_{i t}$

Forecasting null regression: 
$X_{i, t+4}^{(4)}=\mu_{i}+\beta^{\prime} \hat{F}_{t}+\sum_{j=0}^{3} a_{i j} \hat{e}_{i t-j}+$ error,

error,

where $F_{t}$ are the full-sample factors estimated using principal components, ê it is the residual from the factor loading regression and

$X_{i, t}^{(4)}$

is the 4-quarter variable to be forecast.

Series

Split-sample Chow statistics testing the stability of:

Factor loadings 4-step ahead forecasting regressions:

$\left(\Lambda_{i}\right)$

\section{All coefficients Coefficients on Intercept \& on $\boldsymbol{F} t$ coefficients on}

\begin{tabular}{|c|c|c|c|c|}
\hline RGDP & 5.8 & $36.1 * *$ & $11.6 *$ & 5.8 \\
\hline Cons & $11.1^{*}$ & $50.5^{* *}$ & $18.0 * *$ & 2.5 \\
\hline Cons-Dur & $12.6 *$ & $60.2 * *$ & $22.3^{* *}$ & 3.4 \\
\hline Cons-NonDur & $9.9 *$ & $22.5^{* *}$ & $10.2^{*}$ & 8.3 \\
\hline Cons-Serv & 5.1 & $69.0 * *$ & $10.5^{*}$ & $33.8 * *$ \\
\hline GPDInv & 1.6 & $25.1 * *$ & $10.2^{*}$ & 7.3 \\
\hline FixedInv & 6.9 & $46.6 * *$ & $28.6 * *$ & 8.9 \\
\hline NonResInv & 5.0 & $27.4^{* *}$ & $20.9 * *$ & 5.2 \\
\hline $\begin{array}{l}\text { NonResInv- } \\
\text { struct }\end{array}$ & 5.6 & 17.9* & $12.0 *$ & 5.4 \\
\hline $\begin{array}{l}\text { NonResInv- } \\
\text { Bequip }\end{array}$ & 5.9 & $46.0 * *$ & $29.4^{* *}$ & $12.5^{*}$ \\
\hline Res.Inv & 3.2 & $64.1 * *$ & $12.5^{*}$ & $36.8 * *$ \\
\hline Exports & $10.6 *$ & $25.8^{* *}$ & 4.5 & $18.6 * *$ \\
\hline Imports & 3.4 & $23.3^{* *}$ & $12.2 *$ & 3.5 \\
\hline Gov & 7.9 & 7.8 & 3.7 & 3.9 \\
\hline Gov Fed & $12.8 *$ & 8.9 & 5.0 & 3.6 \\
\hline
\end{tabular}




$\begin{array}{lllll}\text { Gov State/Loc } & 4.7 & 13.4 & 1.9 & 11.7^{*} \\ \text { IP: total } & 10.7^{*} & 32.3^{* *} & 12.8^{*} & 4.4 \\ \text { IP: products } & 6.2 & 31.1^{* *} & 11.8^{*} & 7.5 \\ \text { IP: final przod } & 5.6 & 29.6^{* *} & 12.3^{*} & 7.5 \\ \text { IP: cons gds } & 11.3^{*} & 55.4^{* *} & 15.3^{* *} & 19.4^{* *} \\ \text { IP: cons dble } & 9.3 & 20.2^{*} & 9.0 & 2.1 \\ \text { ilP: cons } & 6.0 & 65.6^{* *} & 18.8^{* *} & 13.0^{*} \\ \text { nondble } & & & & \\ \text { IP: bus eqpt } & 5.5 & 34.4^{* *} & 21.2^{* *} & 1.3 \\ \text { IP: matls } & 9.5^{*} & 28.5^{* *} & 14.4^{* *} & 7.1 \\ \text { IP: dble mats } & 8.7 & 28.1^{* *} & 15.7^{* *} & 11.5^{*} \\ \text { IP: nondble } & 9.1 & 71.5^{* *} & 11.0^{*} & 26.8^{* *} \\ \text { mats } & & & & \\ \text { IP: mfg } & 9.5 & 33.4^{* *} & 12.3^{*} & 3.7 \\ \text { IP: fuels } & 4.1 & 10.3 & 3.4 & 3.7 \\ \text { NAPM prodn } & 21.9^{* *} & 36.4^{* *} & 7.3 & 14.3^{*} \\ \text { Capacity Util } & 13.0^{*} & 43.9^{* *} & 26.7^{* *} & 11.0 \\ \text { Emp: total } & 25.3^{* *} & 48.9^{* *} & 20.9^{* *} & 9.9 \\ \text { Emp: gds prod } & 17.7^{* *} & 71.8^{* *} & 23.8^{* *} & 21.1^{* *} \\ \text { Emp: mining } & 2.4 & 17.2^{*} & 8.7 & 9.4 \\ \text { Emp: const } & 14.3^{* *} & 56.9^{* *} & 45.7^{* *} & 16.0^{* *} \\ \text { Emp: mfg } & 22.4^{* *} & 67.5^{* *} & 21.0^{* *} & 22.1^{* *} \\ \text { Emp: dble gds } & 21.5^{* *} & 75.4^{* *} & 26.2^{* *} & 16.8^{* *} \\ \text { Emp: nondbles } & 7.0 & 79.4^{* *} & 11.8^{* *} & 60.1^{* *} \\ \text { Emp: services } & 10.5^{*} & 54.0^{* *} & 20.4^{* *} & 15.6^{* *} \\ \text { Emp: TTU } & 28.0^{* *} & 80.1^{* *} & 34.8^{* *} & 24.6^{* *} \\ \text { Emp: wholesale } & 29.2^{* *} & 76.9^{* *} & 35.1^{* *} & 22.4^{* *} \\ \text { Emp: retail } & 11.8^{* *} & 170.6^{* *} & 48.1^{* *} & 58.5^{* *} \\ \text { Emp: FIRE } & 16.2^{* *} & 99.5^{* *} & 31.9^{* *} & 38.9^{* *} \\ \text { Emp: Govt } & 31.0^{* *} & 30.3^{* *} & 11.1^{*} & 23.0^{* *} \\ & & & & \end{array}$




\begin{tabular}{|c|c|c|c|c|}
\hline $\begin{array}{l}\text { Help wanted } \\
\text { indx }\end{array}$ & $14.3^{* *}$ & $55.7 * *$ & 7.5 & $26.8^{* *}$ \\
\hline $\begin{array}{l}\text { Help wanted/ } \\
\text { emp }\end{array}$ & 1.4 & $24.8^{* *}$ & 7.4 & 12.0* \\
\hline Emp CPS total & $12.4 *$ & $27.2^{* *}$ & $14.6 * *$ & $13.1 *$ \\
\hline Emp CPS nonag & 6.4 & $34.2 * *$ & $11.2^{*}$ & $17.8^{* *}$ \\
\hline Emp. Hours & $28.1^{* *}$ & $69.8^{* *}$ & $31.9 * *$ & 9.4 \\
\hline Avg hrs & 6.6 & $89.4^{* *}$ & 9.1 & $70.0 * *$ \\
\hline Overtime: mfg & 2.1 & $20.9 *$ & 3.0 & 8.3 \\
\hline U: all & $10.6 *$ & $26.3^{* *}$ & $22.5^{* *}$ & 2.5 \\
\hline $\begin{array}{l}\text { U: mean } \\
\text { duration }\end{array}$ & 5.6 & $55.7 * *$ & $15.2^{* *}$ & $27.4 * *$ \\
\hline$U<5 w k s$ & $16.1^{* *}$ & 13.7 & $10.7^{*}$ & 2.7 \\
\hline U 5-14 wks & 5.5 & $17.5^{*}$ & $15.6^{* *}$ & 0.9 \\
\hline U $15+$ wks & 1.5 & $27.2 * *$ & $18.1^{* *}$ & $11.3 *$ \\
\hline U 15-26 wks & 3.1 & $27.5^{* *}$ & $14.9 * *$ & $12.0 *$ \\
\hline U $27+$ wks & 0.4 & $32.1^{* *}$ & $15.8^{* *}$ & $18.1^{* *}$ \\
\hline HStarts: Total & $11.2 *$ & $35.9 * *$ & 8.7 & $14.2 *$ \\
\hline BuildPermits & $9.9 *$ & $25.0 * *$ & $9.8^{*}$ & 6.0 \\
\hline HStarts: NE & 1.7 & $42.2^{* *}$ & 9.3 & $25.7^{* *}$ \\
\hline HStarts: MW & $23.4^{* *}$ & $20.2 *$ & $10.5^{*}$ & 5.2 \\
\hline HStarts: South & $18.1^{* *}$ & $29.6^{* *}$ & $19.6^{* *}$ & 8.0 \\
\hline HStarts: West & 7.7 & $26.5^{* *}$ & $18.0 * *$ & 4.1 \\
\hline PMI & $24.9 * *$ & $31.6 * *$ & 8.9 & $13.6 *$ \\
\hline $\begin{array}{l}\text { NAPM new } \\
\text { ordrs }\end{array}$ & $40.7^{* *}$ & $28.3^{* *}$ & 4.8 & $16.1^{* *}$ \\
\hline $\begin{array}{l}\text { NAPM vendor } \\
\text { del }\end{array}$ & $14.0 * *$ & $17.5^{*}$ & $12.1 *$ & 6.0 \\
\hline NAPM Invent & $18.1^{* *}$ & $75.8^{* *}$ & $16.8^{* *}$ & $50.8^{* *}$ \\
\hline $\begin{array}{l}\text { Orders (Cons- } \\
\text { Goods) }\end{array}$ & $11.7^{*}$ & $38.9 * *$ & $14.0 * *$ & $12.8 *$ \\
\hline
\end{tabular}




\begin{tabular}{|c|c|c|c|c|}
\hline $\begin{array}{l}\text { Orders (NDCap- } \\
\text { Goods) }\end{array}$ & 6.1 & $33.3^{* *}$ & $23.5^{* *}$ & 6.2 \\
\hline PGDP & $9.8^{*}$ & $32.4 * *$ & $26.5^{* *}$ & 1.0 \\
\hline PCED & 2.0 & $23.8^{* *}$ & $18.8^{* *}$ & 3.6 \\
\hline CPI-All & 7.5 & $32.9 * *$ & $22.0 * *$ & 5.4 \\
\hline PCED-Core & 6.7 & $29.5 * *$ & $24.0 * *$ & 5.6 \\
\hline CPI-Core & $19.3^{* *}$ & 14.1 & $9.9 *$ & 5.4 \\
\hline PCED-Dur & 2.2 & $17.2 *$ & $11.6 *$ & 2.8 \\
\hline PCED-motorveh & 2.5 & 9.2 & 6.7 & 3.3 \\
\hline PCED-hhequip & 9.0 & $71.9 * *$ & $61.2^{* *}$ & $14.2^{*}$ \\
\hline PCED-oth dur & 3.2 & $25.1^{* *}$ & $13.4^{* *}$ & $16.3^{* *}$ \\
\hline PCED-nondur & 2.8 & $23.2^{* *}$ & $10.6 *$ & 2.9 \\
\hline PCED-food & 5.3 & $34.6^{* *}$ & $22.7^{* *}$ & 5.9 \\
\hline PCED-clothing & 2.1 & 10.1 & 4.4 & 3.9 \\
\hline PCED-energy & 7.7 & $44.7^{* *}$ & $26.5^{* *}$ & 4.0 \\
\hline $\begin{array}{l}\text { PCED-oth } \\
\text { nondur }\end{array}$ & 5.9 & $17.8^{*}$ & 2.2 & $14.5^{*}$ \\
\hline PCED-services & 4.6 & $57.7^{* *}$ & $45.8^{* *}$ & 4.3 \\
\hline PCED-housing & 2.6 & 5.7 & 4.1 & 2.7 \\
\hline PCED-hhops & 4.5 & 13.0 & 8.7 & 4.1 \\
\hline $\begin{array}{l}\text { PCED-elect } \\
\& \text { gas }\end{array}$ & 4.8 & 9.7 & 3.9 & 3.1 \\
\hline PCED-othhhops & 2.2 & 12.3 & 3.1 & 4.9 \\
\hline PCED-transport & 9.5 & $76.2^{* *}$ & $16.4^{* *}$ & $44.9 * *$ \\
\hline PCED-medical & $24.2 * *$ & $34.3^{* *}$ & $11.8^{*}$ & $12.7 *$ \\
\hline $\begin{array}{l}\text { PCED- } \\
\text { recreation }\end{array}$ & 5.8 & 14.5 & 8.0 & 8.0 \\
\hline PCED-oth serv & 8.6 & $25.5^{* *}$ & 9.3 & 7.3 \\
\hline PGPDI & 8.4 & $21.4^{*}$ & $16.6^{* *}$ & 2.8 \\
\hline $\mathrm{PFI}$ & 5.9 & $27.3^{* *}$ & $15.8^{* *}$ & 7.4 \\
\hline
\end{tabular}




\begin{tabular}{|c|c|c|c|c|}
\hline PFI-nonres & 4.5 & $32.1^{* *}$ & $12.9 *$ & $20.2^{* *}$ \\
\hline $\begin{array}{l}\text { PFI-nonres } \\
\text { struc }\end{array}$ & 6.2 & 14.2 & 6.1 & 9.0 \\
\hline $\begin{array}{l}\text { PFI-nonres } \\
\text { equip }\end{array}$ & 3.6 & 13.9 & $10.8 *$ & 2.3 \\
\hline PFI-resdidential & 4.7 & $59.5^{* *}$ & $21.3^{* *}$ & 10.5 \\
\hline PEXP & 5.1 & $23.8^{* *}$ & $11.4 *$ & $14.3^{*}$ \\
\hline PIMP & 4.3 & $27.1 * *$ & $16.2^{* *}$ & 1.3 \\
\hline PGOV & 3.0 & $22.6 * *$ & $16.8^{* *}$ & 7.0 \\
\hline PGOV-Federal & 1.6 & $23.6 * *$ & 6.1 & 5.5 \\
\hline PGOV-St \& loc & 3.3 & $28.6^{* *}$ & $24.0 * *$ & 4.6 \\
\hline $\begin{array}{l}\text { Com: spot price } \\
\text { (real) }\end{array}$ & 8.1 & $30.1^{* *}$ & $15.3^{* *}$ & 10.0 \\
\hline OilPrice (Real) & $26.9 * *$ & $24.6^{* *}$ & $12.9 *$ & $11.5^{*}$ \\
\hline $\begin{array}{l}\text { NAPM com } \\
\text { price }\end{array}$ & 8.7 & $104.0 * *$ & $22.2^{* *}$ & $62.0 * *$ \\
\hline Real AHE:goods & 5.0 & $58.0 * *$ & $11.9 *$ & $36.1^{* *}$ \\
\hline Real AHE: const & $13.3^{* *}$ & $38.5^{* *}$ & $22.6^{* *}$ & 6.2 \\
\hline Real AHE: mfg & 8.0 & $54.8^{* *}$ & 9.4 & $27.1^{* *}$ \\
\hline Labor Prod & $10.6 *$ & 8.4 & 5.0 & 1.7 \\
\hline $\begin{array}{l}\text { Real Comp/ } \\
\text { Hour }\end{array}$ & $12.5^{*}$ & 8.7 & 5.1 & 4.0 \\
\hline Unit Labor Cost & $18.3^{* *}$ & $45.4 * *$ & 9.0 & $37.7^{* *}$ \\
\hline FedFunds & 8.6 & $48.5^{* *}$ & $33.1^{* *}$ & $12.6 *$ \\
\hline 3 mo T-bill & 4.7 & $43.7^{* *}$ & $32.4 * *$ & $11.5^{*}$ \\
\hline 6 mo T-bill & $15.4^{* *}$ & $32.6^{* *}$ & $16.8^{* *}$ & $12.7^{*}$ \\
\hline 1yr T-bond & $14.8^{* *}$ & $22.8^{* *}$ & $12.0 *$ & $12.2^{*}$ \\
\hline 5 yr T-bond & 8.2 & 9.9 & 1.4 & 7.5 \\
\hline 10yr T-bond & 6.1 & 13.4 & 1.1 & 7.2 \\
\hline Aaabond & $9.6^{*}$ & 14.4 & 4.3 & 6.3 \\
\hline
\end{tabular}




\begin{tabular}{|c|c|c|c|c|}
\hline Baa bond & $11.3 *$ & $17.6^{*}$ & 7.7 & 5.1 \\
\hline fygm6-fygm3 & $22.7^{* *}$ & $34.6^{* *}$ & 4.2 & $24.5^{* *}$ \\
\hline fygt1-fygm3 & $23.2^{* *}$ & $55.7 * *$ & $25.7 * *$ & $14.1 *$ \\
\hline fygt10-fygm3 & $17.4^{* *}$ & $26.4^{* *}$ & $9.7 * *$ & 7.5 \\
\hline fyaaac-fygt10 & 4.9 & $60.4^{* *}$ & $11.7 *$ & $35.5^{* *}$ \\
\hline fybaac-fygt10 & $15.2^{* *}$ & $57.5^{* *}$ & $33.5^{* *}$ & $11.6 *$ \\
\hline M1 & 2.5 & 11.6 & 2.8 & 4.6 \\
\hline MZM & 5.3 & 13.2 & 7.1 & 4.0 \\
\hline M2 & $13.0 *$ & $55.5^{* *}$ & $40.3^{* *}$ & 6.7 \\
\hline MB & 8.1 & $34.4 * *$ & $12.2 *$ & $21.5^{* *}$ \\
\hline Reserves tot & 4.6 & $49.2 * *$ & 9.2 & $22.4 * *$ \\
\hline $\begin{array}{l}\text { Reserves } \\
\text { nonbor }\end{array}$ & 8.7 & 16.1 & $12.1 *$ & 5.7 \\
\hline Bus loans & 3.2 & $38.0 * *$ & $15.3^{* *}$ & 10.7 \\
\hline Cons credit & 3.3 & $20.5^{*}$ & $15.9 * *$ & 2.6 \\
\hline Ex rate: avg & $26.8^{* *}$ & $21.0 *$ & $11.0 *$ & 4.1 \\
\hline Ex rate: Switz & $9.6 *$ & $17.0 *$ & 8.0 & 9.7 \\
\hline Ex rate: Japan & 6.4 & $26.0 * *$ & $9.6 *$ & 10.0 \\
\hline Ex rate: UK & 6.4 & $43.4^{* *}$ & $13.5^{* *}$ & 10.6 \\
\hline $\begin{array}{l}\text { EX rate: } \\
\text { Canada }\end{array}$ & 6.4 & $26.5^{* *}$ & $19.3^{* *}$ & 6.2 \\
\hline S\&P 500 & $11.0 *$ & $22.2 * *$ & $12.4^{*}$ & 6.1 \\
\hline S\&P: indust & $11.1 *$ & $22.7^{* *}$ & $13.3^{*}$ & 5.7 \\
\hline S\&P div yield & $11.3^{*}$ & $21.8^{* *}$ & $15.2^{* *}$ & 5.5 \\
\hline S\&P PE ratio & $18.6^{* *}$ & $56.6^{* *}$ & $37.1^{* *}$ & 7.3 \\
\hline DJIA & 6.8 & $33.0 * *$ & $14.3 * *$ & $15.4 * *$ \\
\hline $\begin{array}{l}\text { Consumer } \\
\text { expect }\end{array}$ & $23.5^{* *}$ & $38.0 * *$ & $18.4 * *$ & 10.2 \\
\hline
\end{tabular}

Notes: Entries are chi-squared Chow statistics computed using Newey-West (1987) standard errors with 4 lags (numeric column 1) and 5 lags (numeric 
columns 2-4). Asterisks indicate that the Chow statistics exceed standard $* 5 \%$ and $* * 1 \%$ critical values.

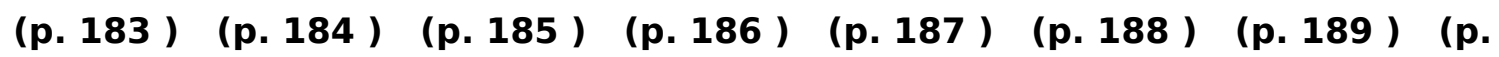
190 ) the full-sample factors and interactions were included to allow the coefficients to differ in the two subsamples. There is considerably more evidence for instability in the forecasting regression than in the factor loadings themselves: $84 \%$ of the Chow statistics testing the stability of all the coefficients in (7.8) reject at the $5 \%$ significance level, and $74 \%$ reject at the $1 \%$ significance level. If we focus on the coefficients on the factors in the forecasting regression, there is again widespread evidence of instability ( $72 \%$ rejections at the $5 \%$ level, $47 \%$ rejections at the $1 \%$ level). There is also evidence of instability in the idiosyncratic dynamics.

The fact that there are strikingly more rejections of stability of the coefficients on $F_{t}$ in the forecasting regressions than in the contemporaneous (factor-loading) regressions is consistent with the dynamics of the factor process changing between the two subsamples, see (7.6), however additional analysis is required to confirm this conjecture.

\section{Stability of forecasting regressions by category of variable being} forecasted. One possibility is that the instability evident in the forecasting equations seen in Table 7.3 is concentrated in a few categories of series. This possibility is explored in Table 7.4, which summarizes the Table 7.3 rejections (at the $5 \%$ significance level) by category of variable. Rejections of stability of the factor loadings are relatively less frequent for output variables, prices and wages, and money and credit variables, and are relatively more frequent for consumption, labour market, housing, and financial variables. No category, however, is immune from instability in the forecasting equations. Moreover,

Table 7.4. Summary of Chow tests by category of variable: Fraction rejections of variables within category at the $5 \%$ significance level

\section{Category Number of Split-sample Chow statistics testing the stability of: series}

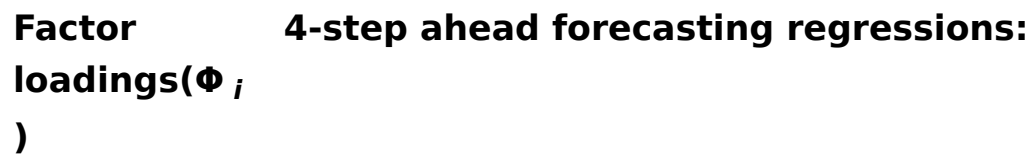


All coefficients

\begin{abstract}
Output
\end{abstract}
Consumption

Labour

market

Housing

Investment,

inventories,

\&orders

Prices \&

wages

Financial

variables

Money \&

credit

Other

All
$14 \quad 0.29$

$4 \quad 0.75$

$27 \quad 0.59$

$7 \quad 0.57$

110.45

$\begin{array}{ll}42 & 0.17\end{array}$

230.61

80.13

0.63

0.63

0.50

0.38

0.84

0.72

$144 \quad 0.41$
Coefficients Intercept \& coefficients

on $u$ it-1

(p. 191 ) for all categories the instability arises more commonly from instability in the coefficients on the factors, which in turn points to instability in the dynamics of the factor process.

\subsubsection{Subsample v. Full-Sample Forecasting Regressions}

We now turn to a comparison of three different direct four-quarter ahead forecasting methods: 'full-full' (that is, full-sample estimates of the factors and full-sample estimates of the forecasting regression (7.8), with $\hat{e}_{i t}$ the residual from the full-sample regression of $X$ it onto the four full-sample factors), 'full-split' (full-sample estimates of the four full-sample factors and split-sample estimates of (7.8), with êit the residual from the splitsample regression of $X$ it onto the four full-sample factors), and 'splitsplit' (split-sample estimates of the three split-sample factors and splitsample estimates of (7.8), with $\hat{e}_{i t}$ the residual from the split-sample regression of $X$ it onto the three split-sample factors). In each case, $p=4$ in (7.8). 
These comparisons are summarized in Table 7.5. Of particular interest are the relative MSEs of the three different methods, which are presented in the third and fourth columns for the pre-84 sample and in the seventh and eighth columns for the post-84 sample. Note that the relative MSEs are computed using the residuals from various fitted regressions, that is, these are insample not pseudo out-of-sample estimates; also note that the method of construction of $\hat{e}_{i t}$ and the lag specification in (7.8) implies that the MSE of the full-full forecast can be less than the MSE of the full-split forecast.

The relative MSEs in Table 7.5 are summarized in Figure 7.5(a) (pre-84 sample) and Figure 7.6(a) (post-84 sample). Part (a) of each figure is a histogram of the MSE of the full-split forecasts to the full-full forecasts. Part (b) is a histogram of the MSE of the split-split forecast to the full-split, so values exceeding 1.0 indicate that the full-split forecast outperforms the split-split forecast.

The hypothesis tests in Table 7.3 examined direct forecasting equations using the full-sample factors, in which the coefficients are allowed to change between the two samples; the finding from Table 7.3, summarized in the second column ('all coefficients') of Table 7.4, is that for most of the series the change in the coefficients in (7.8) is statistically significant. The magnitude of this improvement, measured by relative MSEs, is quantified in the 'full-split to full-full' column of Table 7.5. As can be seen in Figures 7.5(a)(a) and 7.6(a)(a), allowing the forecasting coefficients to change, while using the full-sample factors, typically produces modest improvements in fit in the pre-84 sample but very substantial improvements in fit in the post-84 sample.

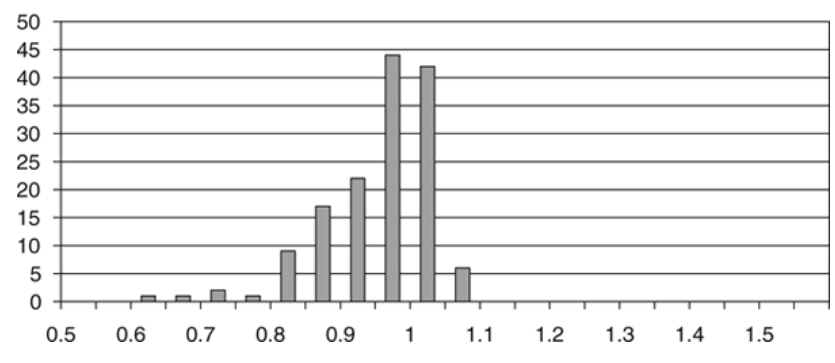

Fig. 7.5(b). Histogram of relative MSEs of split-split forecasts to full-split forecasts, pre- 1984 sample (mean $=1.01$, median $=1.00$ ). 


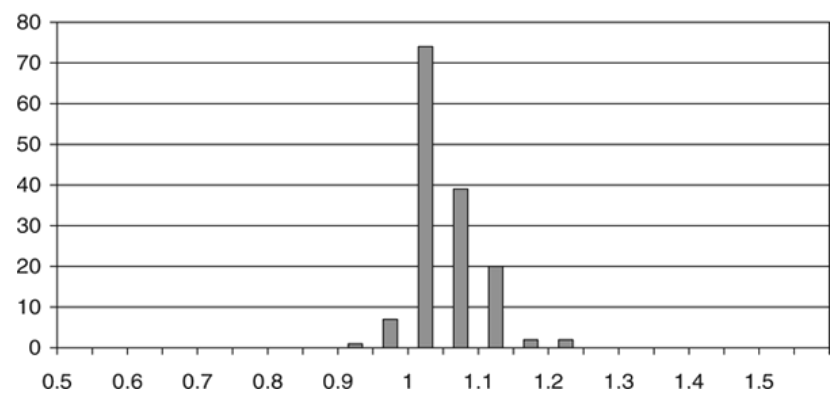

Fig. 7.6(a). Histogram of relative MSEs of full-split forecasts to full-full forecasts, post- 1984 sample $($ mean $=0.75$, median $=0.75$ ).

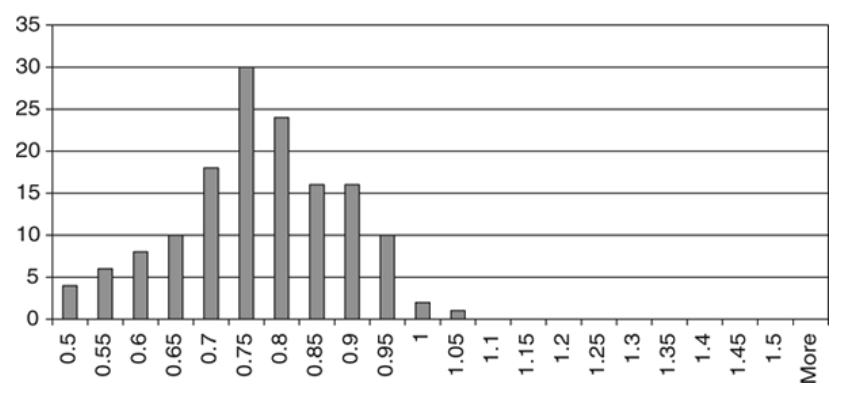

Fig. 7.6(b). Histogram of relative MSEs of split-split forecasts to full-split forecasts, post-1984 sample (mean $=1.07$, median $=1.06$ ).

Given this large and statistically significant change in the forecasting coefficients using the full-sample estimates of the factors, it is natural to wonder whether one might further improve the forecasts using split-sample estimates (p. 192 )

Table 7.5. In-sample root mean square errors (RMSEs) and relative MSEs of 4-step ahead forecasting regressions: 4 full-sample factors, 3 subsample factors

The forecasting regressions (specification (7.8)) are estimated using:

(a) full-sample factor estimates and full-sample coefficients ('full-full')

(b) full-sample factor estimates and split-sample coefficients ('full-split')

(c) split-sample factor estimates and split-sample coefficients ('split-split')

\section{Series Pre-84 Sample $\left(X_{i t}\right)$}

Post-84 Sample 


\begin{tabular}{|c|c|c|c|c|c|c|c|c|}
\hline & \multirow{2}{*}{$\begin{array}{l}\text { Std dev } \\
\text { of } X(4) \text { it }\end{array}$} & \multirow{2}{*}{$\begin{array}{l}\text { RMSE, } \\
\text { full- } \\
\text { full }\end{array}$} & \multicolumn{2}{|c|}{ MSE ratio } & \multirow{2}{*}{$\begin{array}{l}\text { Std dev } \\
\text { of } X(4) \text { it }\end{array}$} & \multirow{2}{*}{$\begin{array}{l}\text { RMSE, } \\
\text { full- } \\
\text { full }\end{array}$} & \multicolumn{2}{|c|}{ MSE ratio } \\
\hline & & & $\begin{array}{l}\text { full- } \\
\text { split to } \\
\text { full- } \\
\text { full }\end{array}$ & $\begin{array}{l}\text { split- } \\
\text { split to } \\
\text { full- } \\
\text { split }\end{array}$ & & & $\begin{array}{l}\text { full- } \\
\text { split to } \\
\text { full- } \\
\text { full }\end{array}$ & $\begin{array}{l}\text { split- } \\
\text { split to } \\
\text { full- } \\
\text { split }\end{array}$ \\
\hline RGDP & 2.73 & 2.13 & 0.94 & 0.99 & 1.29 & 1.23 & 0.69 & 1.17 \\
\hline Cons & 2.16 & 1.80 & 0.95 & 0.99 & 1.11 & 1.08 & 0.71 & 1.16 \\
\hline $\begin{array}{l}\text { Cons- } \\
\text { Dur }\end{array}$ & 7.59 & 5.71 & 0.94 & 0.99 & 4.42 & 4.47 & 0.83 & 1.05 \\
\hline $\begin{array}{l}\text { Cons- } \\
\text { NonDur }\end{array}$ & 2.01 & 1.75 & 0.88 & 1.10 & 1.18 & 1.18 & 0.77 & 1.14 \\
\hline $\begin{array}{l}\text { Cons- } \\
\text { Serv }\end{array}$ & 1.26 & 1.17 & 0.90 & 0.98 & 0.86 & 0.84 & 0.54 & 1.29 \\
\hline GPDInv & 11.97 & 8.28 & 0.90 & 1.01 & 6.72 & 6.27 & 0.80 & 1.07 \\
\hline FixedInv & 7.85 & 5.73 & 0.89 & 1.00 & 5.10 & 4.60 & 0.69 & 1.04 \\
\hline NonResIn & $\mathrm{n} \nabla .47$ & 5.43 & 0.87 & 1.03 & 6.14 & 4.87 & 0.76 & 0.99 \\
\hline $\begin{array}{l}\text { NonResin } \\
\text { struct }\end{array}$ & $\nabla-65$ & 6.62 & 0.87 & 1.00 & 7.71 & 6.17 & 0.80 & 1.01 \\
\hline $\begin{array}{l}\text { NonResIn } \\
\text { Bequip }\end{array}$ & 18.33 & 5.80 & 0.86 & 1.04 & 6.09 & 5.07 & 0.72 & 1.01 \\
\hline Res.Inv & 16.88 & 12.11 & 0.95 & 1.00 & 7.25 & 7.20 & 0.62 & 1.18 \\
\hline Exports & 6.76 & 5.34 & 0.92 & 0.98 & 5.27 & 5.09 & 0.88 & 1.01 \\
\hline Imports & 8.63 & 5.81 & 0.96 & 1.03 & 4.56 & 3.97 & 0.86 & 1.04 \\
\hline Gov & 2.85 & 2.48 & 1.00 & 1.00 & 1.77 & 1.49 & 0.93 & 0.99 \\
\hline Gov Fed & 5.07 & 4.34 & 1.00 & 1.00 & 3.54 & 2.87 & 0.90 & 0.94 \\
\hline $\begin{array}{l}\text { Gov } \\
\text { State/ } \\
\text { Loc }\end{array}$ & 2.51 & 2.08 & 0.99 & 1.00 & 1.61 & 1.32 & 0.82 & 1.05 \\
\hline IP: total & 5.37 & 3.68 & 0.93 & 1.00 & 2.80 & 2.56 & 0.76 & 1.05 \\
\hline $\begin{array}{l}\text { IP: } \\
\text { products }\end{array}$ & 4.58 & 3.25 & 0.92 & 0.99 & 2.46 & 2.23 & 0.74 & 1.09 \\
\hline
\end{tabular}




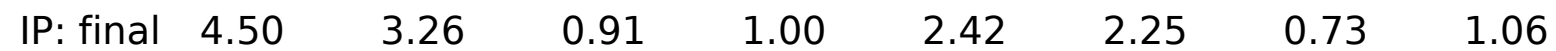

prod

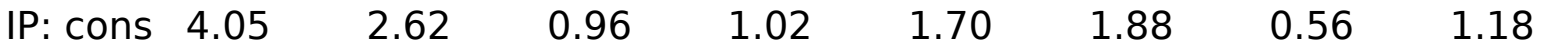

gds

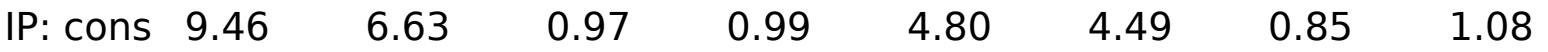

dble

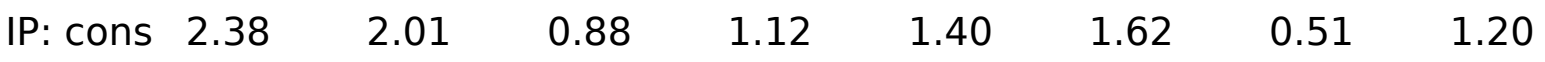

nondble

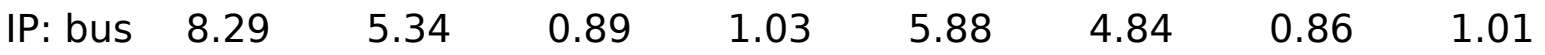
eqpt

$\begin{array}{llllllll} & & \end{array}$

matls

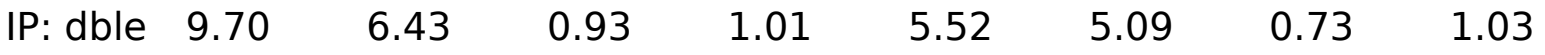

mats

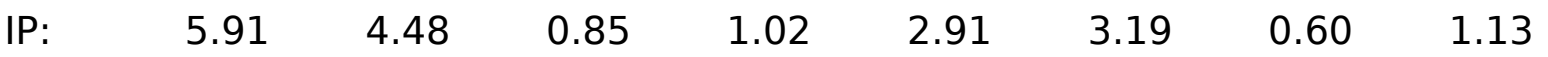

nondble

mats

$\begin{array}{lllllllll}\text { IP: mfg } & 6.00 & 4.08 & 0.93 & 0.99 & 3.18 & 2.84 & 0.78 & 1.06 \\ \text { IP: fuels } & 5.19 & 5.05 & 0.96 & 1.00 & 3.52 & 3.41 & 0.81 & 1.06 \\ \begin{array}{l}\text { NAPM } \\ \text { prodn }\end{array} & 8.00 & 6.97 & 0.96 & 0.98 & 5.56 & 5.27 & 0.80 & 1.20\end{array}$

$\begin{array}{llllllll}\text { Capacity } 5.35 & 3.01 & 0.90 & 1.00 & 3.19 & 2.15 & 0.73 & 1.12\end{array}$

Util

$\begin{array}{lllllllll}\text { Emp: } & 2.36 & 1.61 & 0.89 & 0.96 & 1.53 & 1.00 & 0.61 & 1.15\end{array}$

total

$\begin{array}{lllllllll}\text { Emp: } & 4.20 & 2.78 & 0.90 & 0.97 & 2.44 & 1.79 & 0.58 & 1.13\end{array}$

gds

prod

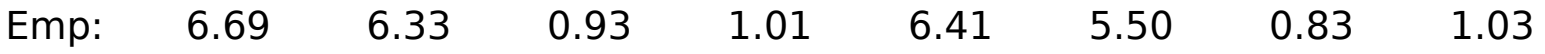

mining

$\begin{array}{lllllllll}\text { Emp: } & 5.45 & 3.99 & 0.92 & 0.98 & 3.89 & 2.87 & 0.70 & 1.09\end{array}$

const

$\begin{array}{lllllllll}\text { Emp: } & 4.26 & 2.97 & 0.86 & 0.98 & 2.48 & 2.03 & 0.49 & 1.11\end{array}$ $\mathrm{mfg}$ 


\begin{tabular}{|c|c|c|c|c|c|c|c|c|}
\hline $\begin{array}{l}\text { Emp: } \\
\text { dble } \\
\text { gds }\end{array}$ & 5.48 & 3.75 & 0.87 & 0.99 & 3.11 & 2.42 & 0.56 & 1.07 \\
\hline $\begin{array}{l}\text { Emp: } \\
\text { nondbles }\end{array}$ & 2.57 & 2.03 & 0.74 & 1.04 & 1.90 & 1.47 & 0.53 & 1.08 \\
\hline $\begin{array}{l}\text { Emp: } \\
\text { services }\end{array}$ & 1.33 & 0.87 & 0.87 & 0.98 & 1.13 & 0.68 & 0.70 & 1.15 \\
\hline $\begin{array}{l}\text { Emp: } \\
\text { TTU }\end{array}$ & 1.78 & 1.26 & 0.81 & 0.99 & 1.59 & 1.06 & 0.62 & 1.19 \\
\hline $\begin{array}{l}\text { Emp: } \\
\text { wholesale }\end{array}$ & $e^{1.88}$ & 1.44 & 0.71 & 1.04 & 1.86 & 1.29 & 0.71 & 1.10 \\
\hline $\begin{array}{l}\text { Emp: } \\
\text { retail }\end{array}$ & 1.74 & 1.28 & 0.79 & 1.01 & 1.64 & 1.21 & 0.58 & 1.19 \\
\hline $\begin{array}{l}\text { Emp: } \\
\text { FIRE }\end{array}$ & 1.29 & 0.88 & 0.85 & 1.01 & 1.63 & 1.19 & 0.75 & 1.12 \\
\hline $\begin{array}{l}\text { Emp: } \\
\text { Govt }\end{array}$ & 1.93 & 1.25 & 0.94 & 1.02 & 0.80 & 0.85 & 0.65 & 1.00 \\
\hline $\begin{array}{l}\text { Help } \\
\text { wanted } \\
\text { indx }\end{array}$ & 3.46 & 2.68 & 0.84 & 1.01 & 2.44 & 1.87 & 0.81 & 1.13 \\
\hline $\begin{array}{l}\text { Help } \\
\text { wanted/ } \\
\text { emp }\end{array}$ & 0.09 & 0.07 & 0.97 & 1.01 & 0.04 & 0.04 & 0.71 & 1.07 \\
\hline $\begin{array}{l}\text { Emp } \\
\text { CPS } \\
\text { total }\end{array}$ & 1.55 & 1.15 & 0.86 & 0.99 & 0.98 & 0.78 & 0.65 & 1.38 \\
\hline $\begin{array}{l}\text { Emp } \\
\text { CPS } \\
\text { nonag }\end{array}$ & 1.58 & 1.16 & 0.84 & 0.98 & 1.03 & 0.83 & 0.64 & 1.38 \\
\hline $\begin{array}{l}\text { Emp. } \\
\text { Hours }\end{array}$ & 2.70 & 1.92 & 0.85 & 0.98 & 1.98 & 1.61 & 0.68 & 1.08 \\
\hline Avg hrs & 0.50 & 0.35 & 0.98 & 0.98 & 0.42 & 0.31 & 0.89 & 0.99 \\
\hline $\begin{array}{l}\text { Overtime } \\
\mathrm{mfg}\end{array}$ & 0.12 & 0.08 & 0.93 & 1.00 & 0.08 & 0.07 & 0.91 & 1.06 \\
\hline
\end{tabular}



U: all
0.30
$0.20 \quad 0.95$
1.01
0.16
0.12
0.71
1.23
$\mathrm{U}$ :
0.55
0.29
0.92
1.03
0.43
0.25
0.68
1.17

mean

duration

$U<5 \quad 9.85$

$8.13 \quad 0.93$

1.02

6.50

6.14

0.85

1.10

wks
U 5-14
21.00
$15.44 \quad 0.96$
1.01
11.52
9.60
0.76
1.24 wks

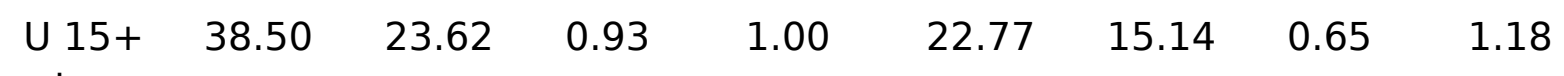
wks

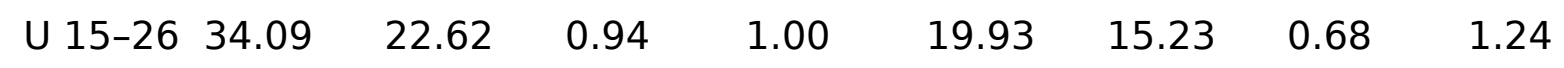
wks
U 27+
46.91
$27.03 \quad 0.95$
1.02
27.70
16.88
0.67
1.23

wks
HStarts: 0.23
0.19
0.94
1.01
0.18
0.12
0.78
0.99

Total

$\begin{array}{llllllll}\text { BuildPerm0tz6 } & 0.21 & 0.98 & 0.98 & 0.21 & 0.13 & 0.77 & 0.98 \\ \text { HStarts: } 0.30 & 0.21 & 0.96 & 0.97 & 0.27 & 0.15 & 0.79 & 1.10 \\ \text { NE } & & & & & & & \end{array}$

HStarts: $\begin{array}{llllllll}0.32 & 0.25 & 1.00 & 1.00 & 0.14 & 0.11 & 0.98 & 1.08\end{array}$
MW

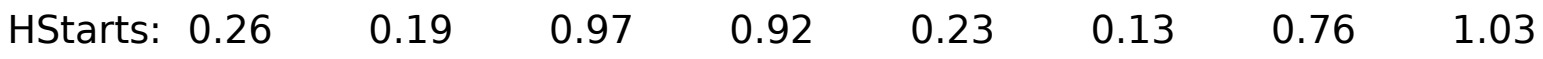

South

$\begin{array}{llllllll}\text { HStarts: } 0.33 & 0.24 & 0.99 & 1.00 & 0.20 & 0.14 & 0.84 & 1.03\end{array}$ West

$\begin{array}{lllllllll}\text { PMI } & 7.82 & 6.70 & 0.93 & 0.94 & 4.66 & 4.55 & 0.73 & 1.22 \\ \begin{array}{l}\text { NAPM } \\ \text { new }\end{array} & 8.58 & 7.38 & 0.98 & 0.99 & 5.85 & 5.43 & 0.80 & 1.23 \\ \begin{array}{l}\text { ordrs } \\ \text { NAPM }\end{array} & 13.51 & 11.12 & 0.95 & 0.97 & 4.66 & 5.17 & 0.56 & 1.18 \\ \begin{array}{l}\text { vendor } \\ \text { del }\end{array} & & & & & & & & \\ \begin{array}{l}\text { NAPM } \\ \begin{array}{l}\text { Invent } \\ \text { Inver }\end{array}\end{array} & 7.68 & 6.39 & 0.84 & 0.90 & 3.15 & 3.59 & 0.42 & 1.22\end{array}$


$\begin{array}{lllllllll}\text { Orders } & 8.51 & 6.34 & 0.87 & 0.96 & 3.49 & 3.61 & 0.68 & 1.06\end{array}$ (ConsGoods)

$\begin{array}{lrlllllll}\begin{array}{l}\text { Orders } \\ \text { (NDCapGoods) }\end{array} & 15.02 & 10.98 & 0.89 & 1.01 & 9.89 & 8.66 & 0.78 & 1.00 \\ \text { PGDP } & 1.43 & 0.99 & 0.96 & 0.99 & 0.73 & 0.59 & 0.63 & 1.13 \\ \text { PCED } & 1.49 & 1.17 & 0.97 & 0.98 & 0.99 & 0.80 & 0.69 & 1.10 \\ \text { CPI-All } & 1.98 & 1.33 & 0.95 & 1.00 & 1.39 & 1.14 & 0.70 & 1.02 \\ \text { PCED- } & 1.24 & 0.98 & 0.98 & 1.01 & 0.60 & 0.49 & 0.60 & 1.16 \\ \text { Core } & & & & & & & & \\ \text { CPI- } & 1.99 & 1.74 & 0.98 & 1.04 & 0.55 & 0.56 & 0.54 & 1.07\end{array}$

Core

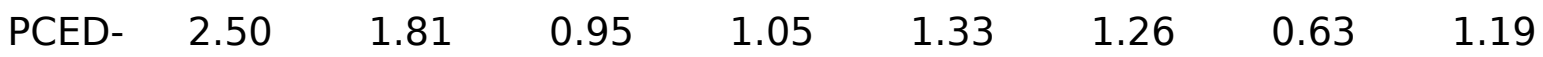

Dur

$\begin{array}{lllllllll}\text { PCED- } & 4.17 & 2.86 & 0.98 & 1.02 & 2.30 & 1.89 & 0.83 & 1.04\end{array}$ motorveh

$\begin{array}{lllllllll}\text { PCED- } & 1.92 & 1.44 & 0.91 & 1.08 & 1.82 & 1.47 & 0.59 & 1.15\end{array}$

hhequip

$\begin{array}{lllllllll}\text { PCED- } & 2.87 & 2.36 & 0.96 & 1.02 & 2.00 & 1.34 & 0.72 & 1.28\end{array}$

oth dur

$\begin{array}{lllllllll}\text { PCED- } & 2.59 & 1.99 & 0.95 & 0.95 & 2.95 & 1.99 & 0.90 & 1.03\end{array}$

nondur

$\begin{array}{lllllllll}\text { PCED- } & 3.28 & 2.33 & 1.00 & 0.98 & 1.24 & 0.99 & 0.75 & 1.16\end{array}$

food

$\begin{array}{lllllllll}\text { PCED- } & 2.14 & 1.58 & 0.95 & 1.07 & 3.03 & 1.78 & 0.87 & 1.08\end{array}$

clothing

$\begin{array}{lllllllll}\text { PCED- } & 14.29 & 11.06 & 0.83 & 0.99 & 27.93 & 18.87 & 1.01 & 0.93\end{array}$

energy

$\begin{array}{lllllllll}\text { PCED- } & 2.49 & 1.91 & 0.91 & 1.04 & 1.59 & 1.19 & 0.75 & 1.09\end{array}$

oth

nondur

$\begin{array}{lllllllll}\text { PCED- } & 1.21 & 0.91 & 0.98 & 0.97 & 0.82 & 0.55 & 0.76 & 1.00\end{array}$ services

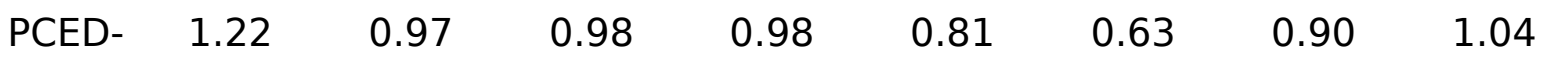
housing 


\begin{tabular}{|c|c|c|c|c|c|c|c|c|}
\hline $\begin{array}{l}\text { PCED- } \\
\text { hhops }\end{array}$ & 2.40 & 1.82 & 0.92 & 0.98 & 3.50 & 2.31 & 0.94 & 1.07 \\
\hline $\begin{array}{l}\text { PCED- } \\
\text { elect \& } \\
\text { gas }\end{array}$ & 3.78 & 2.90 & 0.70 & 1.02 & 7.30 & 5.90 & 0.92 & 1.01 \\
\hline $\begin{array}{l}\text { PCED- } \\
\text { oth } \\
\text { hhops }\end{array}$ & 2.74 & 2.23 & 0.97 & 1.01 & 1.72 & 1.19 & 0.78 & 1.16 \\
\hline $\begin{array}{l}\text { PCED- } \\
\text { transport }\end{array}$ & 6.80 & 5.04 & 0.57 & 1.07 & 6.60 & 7.15 & 0.71 & 0.99 \\
\hline $\begin{array}{l}\text { PCED- } \\
\text { medical }\end{array}$ & 1.80 & 1.42 & 0.93 & 1.00 & 0.94 & 0.97 & 0.71 & 1.01 \\
\hline $\begin{array}{l}\text { PCED- } \\
\text { recreation }\end{array}$ & 1.72 & 1.13 & 1.03 & 0.97 & 1.10 & 0.77 & 0.87 & 1.08 \\
\hline $\begin{array}{l}\text { PCED- } \\
\text { oth serv }\end{array}$ & 2.59 & 2.13 & 0.96 & 1.00 & 2.71 & 1.97 & 0.76 & 0.84 \\
\hline PGPDI & 2.63 & 1.72 & 0.95 & 1.08 & 1.25 & 1.19 & 0.54 & 1.13 \\
\hline PFI & 2.66 & 1.75 & 0.94 & 1.06 & 1.29 & 1.20 & 0.55 & 1.11 \\
\hline $\begin{array}{l}\text { PFI- } \\
\text { nonres }\end{array}$ & 2.60 & 1.89 & 0.91 & 1.07 & 1.32 & 1.23 & 0.59 & 1.08 \\
\hline PFI- & 3.68 & 2.90 & 0.96 & 1.01 & 2.12 & 1.81 & 0.73 & 8 \\
\hline
\end{tabular}

nonres

struc

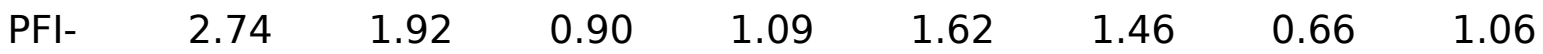
nonres

equip

$\begin{array}{lllllllll}\text { PFI- } & 4.53 & 4.08 & 0.98 & 1.00 & 2.21 & 1.94 & 0.43 & 1.01\end{array}$
resdidential

$\begin{array}{lllllllll}\text { PEXP } & 5.17 & 3.93 & 0.97 & 0.95 & 2.38 & 2.19 & 0.69 & 1.11 \\ \text { PIMP } & 8.49 & 7.55 & 0.95 & 0.96 & 6.58 & 4.79 & 0.83 & 1.00 \\ \text { PGOV } & 2.29 & 1.34 & 0.89 & 1.00 & 1.62 & 1.11 & 0.71 & 1.02 \\ \text { PGOV- } & 3.89 & 1.86 & 0.95 & 1.01 & 2.72 & 1.25 & 0.87 & 0.99\end{array}$

Federal 
$\begin{array}{lllllllll}\text { PGOV- } & 1.94 & 1.40 & 0.89 & 0.97 & 1.55 & 1.27 & 0.68 & 1.06\end{array}$

St \& loc

$\begin{array}{lllllllll}\text { Com: } & 12.85 & 9.93 & 0.88 & 1.06 & 9.21 & 8.58 & 0.77 & 1.06\end{array}$

spot

price

(real)

$\begin{array}{lllllllll}\text { OilPrice } & 11.51 & 11.16 & 0.72 & 1.00 & 24.19 & 21.91 & 0.82 & 1.01\end{array}$

(Real)

$\begin{array}{lllllllll}\text { NAPM } & 12.95 & 11.27 & 0.86 & 0.94 & 13.22 & 13.50 & 0.66 & 1.14\end{array}$

com

price

$\begin{array}{lllllllll}\text { Real } & 1.49 & 1.37 & 0.91 & 1.06 & 1.16 & 0.86 & 0.74 & 1.09\end{array}$

AHE:

goods

$\begin{array}{lllllllll}\text { Real } & 2.60 & 1.93 & 0.98 & 1.02 & 1.43 & 1.20 & 0.80 & 0.97\end{array}$

AHE:

const

$\begin{array}{lllllllll}\text { Real } & 1.40 & 1.36 & 0.87 & 1.04 & 1.07 & 0.92 & 0.72 & 1.09\end{array}$

AHE:

$\mathrm{mfg}$

$\begin{array}{lllllllll}\text { Labor } & 1.95 & 1.76 & 0.95 & 1.03 & 1.28 & 1.17 & 0.84 & 1.00\end{array}$

Prod

$\begin{array}{lllllllll}\text { Real } & 1.24 & 1.11 & 0.93 & 1.07 & 1.58 & 1.53 & 0.96 & 1.01\end{array}$

Comp/

Hour

$\begin{array}{lllllllll}\text { Unit } & 3.74 & 2.43 & 1.01 & 0.94 & 1.38 & 1.54 & 0.59 & 1.05\end{array}$

Labor

Cost

$\begin{array}{llllllll}\text { FedFunds0.63 } & 0.44 & 0.89 & 0.97 & 0.38 & 0.32 & 0.66 & 1.03\end{array}$

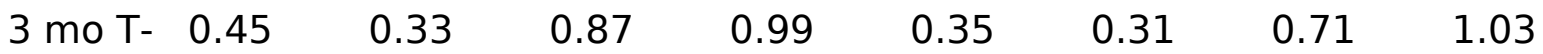

bill

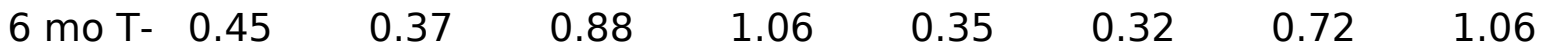

bill

$\begin{array}{lllllllll}1 \mathrm{yr} \text { T- } & 0.46 & 0.39 & 0.89 & 1.08 & 0.36 & 0.33 & 0.79 & 1.07\end{array}$ bond 
$\begin{array}{lllllllll}5 \mathrm{yr} \text { T- } & 0.34 & 0.31 & 0.93 & 1.04 & 0.30 & 0.30 & 0.89 & 0.94\end{array}$ bond

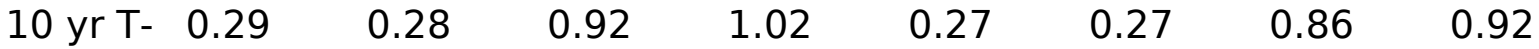
bond

$\begin{array}{lrlllllll}\text { Aaabond } 0.26 & 0.24 & 0.93 & 1.03 & 0.21 & 0.22 & 0.86 & 0.92 \\ \begin{array}{l}\text { Baa } \\ \text { bond }\end{array} & 0.30 & 0.26 & 0.92 & 1.03 & 0.21 & 0.21 & 0.86 & 0.93 \\ \begin{array}{l}\text { fygm6- } \\ \text { fygm3 }\end{array} & 0.22 & 0.21 & 0.95 & 1.01 & 0.14 & 0.14 & 0.73 & 1.12 \\ \text { fygt1- } & 0.46 & 0.40 & 0.85 & 1.08 & 0.31 & 0.33 & 0.70 & 1.09\end{array}$

fygm3

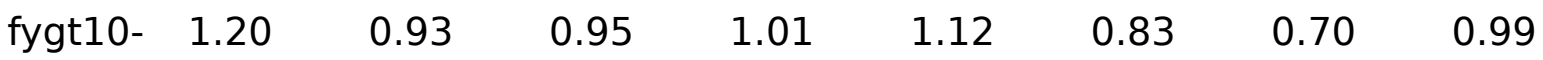
fygm3

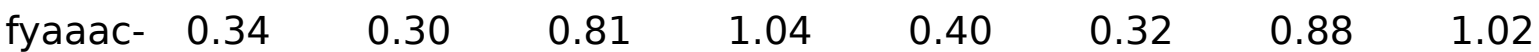
fygt10

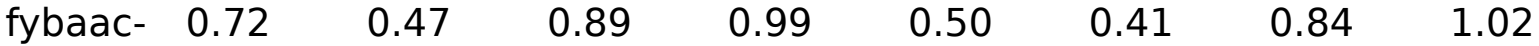
fygt10

$\begin{array}{lrlllllll}\text { M1 } & 3.16 & 2.08 & 0.87 & 1.01 & 4.40 & 3.77 & 0.94 & 0.84 \\ \text { MZM } & 5.97 & 5.29 & 0.96 & 0.96 & 5.08 & 4.61 & 0.81 & 0.81 \\ \text { M2 } & 3.09 & 2.23 & 0.87 & 1.03 & 2.49 & 2.23 & 0.71 & 0.84 \\ \text { MB } & 1.82 & 1.41 & 0.81 & 0.98 & 2.94 & 2.73 & 0.96 & 0.97 \\ \begin{array}{l}\text { Reserves 5.25 } \\ \text { tot }\end{array} & 4.02 & 0.60 & 0.98 & 8.64 & 7.43 & 0.84 & 0.98 \\ \begin{array}{l}\text { Reserves } 12.74 \\ \text { nonbor }\end{array} & 12.73 & 0.77 & 1.08 & 14.49 & 13.04 & 0.76 & 1.03 \\ \begin{array}{l}\text { Bus } \\ \text { loans }\end{array} & 6.71 & 4.90 & 0.91 & 1.03 & 4.91 & 4.07 & 0.79 & 1.08 \\ \begin{array}{l}\text { Cons } \\ \text { credit }\end{array} & 4.23 & 3.07 & 0.87 & 1.03 & 3.48 & 3.37 & 0.84 & 1.01 \\ \begin{array}{l}\text { Ex rate: } \\ \text { avg }\end{array} & & & & & & & & \\ \begin{array}{l}\text { Ex rate: } \\ \text { Switz }\end{array} & 9.70 & 4.51 & 0.86 & 0.97 & 7.62 & 6.97 & 0.90 & 1.14 \\ \end{array}$




\begin{tabular}{|c|c|c|c|c|c|c|c|c|}
\hline $\begin{array}{l}\text { Ex rate: } \\
\text { Japan }\end{array}$ & 8.71 & 7.93 & 0.87 & 1.13 & 12.59 & 11.72 & 0.92 & 1.06 \\
\hline $\begin{array}{l}\text { Ex rate: } \\
\text { UK }\end{array}$ & 9.05 & 8.29 & 0.78 & 1.01 & 9.12 & 8.99 & 0.77 & 1.22 \\
\hline $\begin{array}{l}\text { EX rate: } \\
\text { Canada }\end{array}$ & 3.37 & 3.69 & 0.75 & 1.04 & 5.58 & 4.55 & 0.93 & 0.96 \\
\hline $\begin{array}{l}S \& P \\
500\end{array}$ & 14.28 & 12.57 & 0.79 & 1.05 & 14.21 & 14.72 & 0.74 & 1.00 \\
\hline $\begin{array}{l}\text { S\&P: } \\
\text { indust }\end{array}$ & 14.66 & 13.04 & 0.80 & 1.05 & 15.08 & 15.34 & 0.76 & 1.02 \\
\hline $\begin{array}{l}S \& P \text { div } \\
\text { yield }\end{array}$ & 0.17 & 0.12 & 0.90 & 1.12 & 0.09 & 0.10 & 0.61 & 0.99 \\
\hline $\begin{array}{l}S \& P P E \\
\text { ratio }\end{array}$ & 0.68 & 0.54 & 0.69 & 1.12 & 1.27 & 1.07 & 0.79 & 1.01 \\
\hline DJIA & 14.09 & 11.83 & 0.78 & 1.03 & 13.06 & 14.01 & 0.67 & 1.00 \\
\hline $\begin{array}{l}\text { Consume } \\
\text { expect }\end{array}$ & 22.92 & 2.12 & 0.83 & 1.01 & 2.46 & 2.52 & 0.69 & 1.01 \\
\hline
\end{tabular}

(p. 193 ) (p. 194 ) (p. 195 ) of the factors. This possibility is examined in the 'split-split to full-split' columns of Table 7.5 and in Figures 7.5(a) (b) and 7.6(b). In the pre-84 sample, there is little difference on average across the series between using the full- and split-sample factors. In contrast, in the post-84 sample there is noticeable deterioration on average, and substantial degradation for many individual series, when forecasts are made using the split-sample factors. Strikingly, despite the evidence of some instability in the factor loadings, it is best to (p. 196 ) use all the data to estimate the factors, but to allow the coefficients of the forecasting regressions to change.

As mentioned above, there is ambiguity concerning the number of factors, and the computations underlying Tables 7.3-7.5 were repeated for various numbers of full-sample factors and subsample factors (specifically, 4 and 4,5 and 4 , and 5 and 5, respectively). The main findings stated above are robust to these changes in the estimated factors. The results for 4 and 4 , 5 and 4 , and 5 and 5 factors, like those in Table 7.4 for 4 and 3 factors, are also consistent with the full-sample factor estimates spanning the space of the subsample factor estimates, but the predictive regressions having coefficients which are unstable across subsamples. 


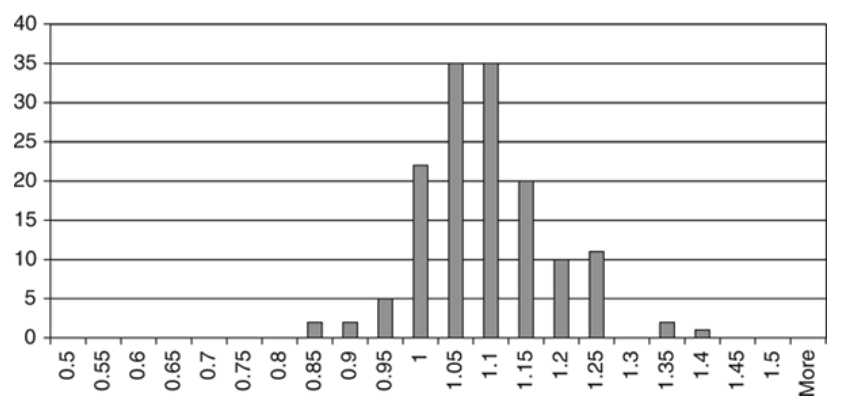

Fig. 8.1. Annual real output growth 1981 to 2005 using the latest data vintage (2006:Q1) and the second release vintage ('real-time(').

(p. 197 )

\subsection{Discussion and Conclusions}

Several caveats are in order concerning the empirical results. The empirical investigation has focused on the single-break model, and multiple breaks and continuous parameter evolution have been ignored. The break date, 1984, has been treated as known a priori, however it was chosen because of a number of interesting macroeconomic transitions that have been noticed around 1984 and thus the break date should in fact be thought of as estimated (although not on the basis of breaks in a factor model). The forecasting regressions examined here are all in-sample estimates and might not reflect out-of-sample performance. Finally, the formal theoretical justification for some of this work is limited. In particular, Stock and Watson (2002b), theorem 3, only states that the space of the factors will be consistently estimated, and it does not formally justify the application of the Bai-Ng (2002) criteria or the use of the factors as regressors (existing proofs of these have time-invariant factor loadings, eg Bai and $\mathrm{Ng}, 2006$ ). These extensions of Stock and Watson (2002b), theorem 3, remain a topic of ongoing research.

Despite these caveats, the results suggest three interesting conclusions. First, there is considerable evidence of instability in the factor model; the indirect evidence suggests instability in all elements (the factor loadings, the factor dynamics, and the idiosyncratic dynamics). Second, despite this instability, the factors seem to be well estimated using the full sample: the full-sample estimates of the factors span the space of the split-sample factor estimates. Third, we have the striking finding that forecasting equations estimated using full-sample estimates of the factors and subsample estimates of the coefficients fit better than equations estimated using 
subsample estimates of both the (p. 198 ) factors and coefficients. This final finding is rather remarkable and is consistent with the theoretical results and Monte Carlo findings in Stock and Watson (1998, 2002b) and Banerjeee, Marcellino, and Masten (2007). It also suggests that when factor forecasts start to break down in practical applications, attention should initially be focused on instability of the forecasting equation instead of problems with the estimates of the factors.

\section{Data Appendix}

Table A.1 lists the short name of each series, its mnemonic (the series label used in the source database), the transformation applied to the series, and a brief data description. All series are from the Global Insight Basic Economics Database, unless the source is listed (in parentheses) as TCB (The Conference Board's Indicators Database) or AC (author's calculation based on Global Insight or TCB data). The binary entry in Table A.1 the column labelled 'E.F.?' indicates whether that variable was used to estimate the factors. For series available monthly, quarterly values were computed by averaging (in native units) the monthly values over the quarter. There are no missing observations.

The transformation codes in the third column of Table A.1 are defined in the subsequent table, along with the $h$-period ahead version of the variable used in the direct forecasting regressions. In this table, $Y_{i t}$ denotes the original (native) untransformed quarterly series.

(p. 199 )

Table A1. Data sources, transformations, and definitions

\begin{tabular}{|c|c|c|c|c|}
\hline Short name & Mnemonic & Trans. Code & E.F.? & Description \\
\hline RGDP & GDP251 & 5 & 0 & $\begin{array}{c}\text { Real gross } \\
\text { domestic } \\
\text { product, } \\
\text { quantity } \\
\text { index (2, } \\
000=100) \text {, saar }\end{array}$ \\
\hline Cons & GDP252 & 5 & 0 & $\begin{array}{l}\text { Real personal } \\
\text { consumption } \\
\text { expenditures, } \\
\text { quantity index }\end{array}$ \\
\hline
\end{tabular}


$(2,000=$

100), saar

Cons-Dur

GDP253

5

1

Real personal

consumption

expenditures

- durable

goods, quantity

index (2,

$000=100$ ), saar

Cons-NonDur

GDP254

5

1

Real personal

consumption

expenditures

- nondurable

goods, quantity

index (2,

$000=100$ ), saar

Cons-Serv

GDP255

5

1

Real personal consumption expenditures

- services, quantity index

$(2,000=$ 100), saar

GPDInv

GDP256

5

0

Real gross private domestic investment, quantity index

$(2,000=$

100), saar

Fixedlnv

GDP257

5

0

Real gross

private

domestic

investment

- fixed

investment, quantity index (2, $000=100$ ), saar 


\begin{tabular}{|c|c|c|c|c|}
\hline NonResInv & GDP258 & 5 & 0 & $\begin{array}{c}\text { Real gross } \\
\text { private } \\
\text { domestic } \\
\text { investment - } \\
\text { nonresidential, } \\
\text { quantity } \\
\text { index ( } 2 \text {, } \\
000=100) \text {, saar }\end{array}$ \\
\hline $\begin{array}{l}\text { NonResInv- } \\
\text { struct }\end{array}$ & GDP259 & 5 & 1 & $\begin{array}{c}\text { Real gross } \\
\text { private } \\
\text { domestic } \\
\text { investment - } \\
\text { nonresidential } \\
\text { - structures, } \\
\text { quantity }\end{array}$ \\
\hline $\begin{array}{l}\text { NonResInv- } \\
\text { Bequip }\end{array}$ & GDP260 & 5 & 1 & $\begin{array}{c}\text { Real gross } \\
\text { private } \\
\text { domestic } \\
\text { investment - } \\
\text { nonresidential } \\
\text { - equipment } \\
\text { \& software }\end{array}$ \\
\hline Res.Inv & GDP261 & 5 & 1 & $\begin{array}{c}\text { Real gross } \\
\text { private } \\
\text { domestic } \\
\text { investment } \\
\text { - residential, } \\
\text { quantity } \\
\text { index (2, } \\
000=100) \text {, saar }\end{array}$ \\
\hline Exports & GDP263 & 5 & 1 & $\begin{array}{c}\text { Real exports, } \\
\text { quantity } \\
\text { index }(2, \\
000=100) \text {, saar }\end{array}$ \\
\hline Imports & GDP264 & 5 & 1 & $\begin{array}{c}\text { Real imports, } \\
\text { quantity } \\
\text { index }(2, \\
000=100) \text {, saar }\end{array}$ \\
\hline
\end{tabular}


Gov

GDP265

5

0

Real

government

consumption

expenditures

$\&$ gross

investment, quantity index

$(2,000=$

100), saar

Gov Fed

GDP266

5

1

Real

government

consumption

expenditures

$\&$ gross

investment

- federal,

quantity

Gov State/Loc

GDP267

5

1

Real

government

consumption

expenditures

$\&$ gross

investment

- state \&

local, quantity

IP: total

IPS10

5

0

Industrial

production

index -

total index

IP: products

IPS11

5

0

Industrial

production

index -

products, total

IP: final prod

IPS299

5

0

Industrial

production

index - final

products 
IP: cons gds

IPS12

5

0

IPS13

IP: cons dble

IP: cons

IPS18

nondble

IP: bus eqpt

IPS25

IPS32

IP: matls

IP: dble mats

IPS34

IPS38

mats

IP: $\mathrm{mfg}$
IPS43
5

5

5

5

1

1

1

5

5

1

1

0

1

(1)
index -
durable goods materials

Industrial production index nondurable goods materials Industrial production 
index -

manufacturing

(sic)

IP: fuels

IPS306

5

1

NAPM prodn

Capacity Util

UTL11

1

1

5

5

Emp: gds prod

CES003

CES006

CES011

5

5

5

Emp: dble gds

CES017

CES033

1

1

Napm

production

index (percent)

Capacity utilization manufacturing

(sic)

Employees, nonfarm total private

Employees, nonfarm

- goods-

producing

5

1

Employees, nonfarm

- mining

Employees, nonfarm construction

Emp: mfg

CES015

0

Employees, nonfarm - mfg

Employees, nonfarm durable goods

Emp: nondbles
5

\section{Employees, nonfarm - nondurable goods}




\begin{tabular}{|c|c|c|c|c|}
\hline Emp: services & CES046 & 5 & 1 & $\begin{array}{l}\text { Employees, } \\
\text { nonfarm - } \\
\text { service- } \\
\text { providing }\end{array}$ \\
\hline Emp: TTU & CES048 & 5 & 1 & $\begin{array}{l}\text { Employees, } \\
\text { nonfarm } \\
\text { - trade, } \\
\text { transport, } \\
\text { utilities }\end{array}$ \\
\hline Emp: wholesale & CES049 & 5 & 1 & $\begin{array}{c}\text { Employees, } \\
\text { nonfarm - } \\
\text { wholesale trade }\end{array}$ \\
\hline Emp: retail & CES053 & 5 & 1 & $\begin{array}{l}\text { Employees, } \\
\text { nonfarm - } \\
\text { retail trade }\end{array}$ \\
\hline Emp: FIRE & CES088 & 5 & 1 & $\begin{array}{c}\text { Employees, } \\
\text { nonfarm - } \\
\text { financial } \\
\text { activities }\end{array}$ \\
\hline Emp: Govt & CES140 & 5 & 1 & $\begin{array}{l}\text { Employees, } \\
\text { nonfarm - } \\
\text { government }\end{array}$ \\
\hline $\begin{array}{l}\text { Help wanted } \\
\text { indx }\end{array}$ & LHEL & 2 & 1 & $\begin{array}{c}\text { Index of } \\
\text { help-wanted } \\
\text { advertising in } \\
\text { newspapers } \\
(1967= \\
100 ; \mathrm{sa})\end{array}$ \\
\hline $\begin{array}{l}\text { Help wanted/ } \\
\text { emp }\end{array}$ & LHELX & 2 & 1 & $\begin{array}{l}\text { Employment: } \\
\text { ratio; help- } \\
\text { wanted ads:no. } \\
\text { Unemployed clf }\end{array}$ \\
\hline Emp CPS total & LHEM & 5 & 0 & $\begin{array}{c}\text { Civilian } \\
\text { labor force: } \\
\text { employed, total } \\
\text { (thous., sa) }\end{array}$ \\
\hline
\end{tabular}




\begin{tabular}{|c|c|c|c|c|}
\hline Emp CPS nonag & LHNAG & 5 & 1 & $\begin{array}{c}\text { Civilian } \\
\text { labor force: } \\
\text { employed, } \\
\text { nonagric.industries } \\
\text { (thous., sa) }\end{array}$ \\
\hline Emp. Hours & LBMNU & 5 & 1 & $\begin{array}{l}\text { Hours of all } \\
\text { persons: } \\
\text { nonfarm } \\
\text { business } \\
\text { sec }(1982 \\
=100, \text { sa) }\end{array}$ \\
\hline Avg hrs & CES151 & 1 & 1 & $\begin{array}{l}\text { Avg wkly } \\
\text { hours, prod } \\
\text { wrkrs, nonfarm } \\
\text { - goods- } \\
\text { producing }\end{array}$ \\
\hline Overtime: mfg & CES155 & 2 & 1 & $\begin{array}{l}\text { Avg wkly } \\
\text { overtime hours, } \\
\text { prod wrkrs, } \\
\text { nonfarm - mfg }\end{array}$ \\
\hline U: all & LHUR & 2 & 1 & $\begin{array}{l}\text { Unemployment } \\
\text { rate: all } \\
\text { workers, } \\
16 \text { years \& } \\
\text { over }(\%, \mathrm{sa})\end{array}$ \\
\hline $\begin{array}{l}\text { U: mean } \\
\text { duration }\end{array}$ & LHU680 & 2 & 1 & $\begin{array}{c}\text { Unemploy.by } \\
\text { duration: } \\
\text { average(mean)duration } \\
\text { in weeks (sa) }\end{array}$ \\
\hline$U<5 w k s$ & LHU5 & 5 & 1 & $\begin{array}{l}\text { Unemploy.by } \\
\text { duration: } \\
\text { persons } \\
\text { unempl.less } \\
\text { than } 5 \text { wks } \\
\text { (thous., sa) }\end{array}$ \\
\hline U 5-14wks & LHU14 & 5 & 1 & $\begin{array}{l}\text { Unemploy.by } \\
\text { duration: } \\
\text { persons }\end{array}$ \\
\hline
\end{tabular}


unempl.5 to 14

wks (thous., sa)

\begin{abstract}
U $15+$ wks
\end{abstract}
LHU15

5

1

LHU26

LHU27

HSFR

HStarts: Total

HSBR

BuildPermits

HSNE

HSMW
5

1

4

5

1

4

0

4

0

1

1

4
Unemploy.by duration:

persons unempl. 15 wks+ (thous., sa)

Unemploy.by duration: persons unempl.15 to 26 wks (thous., sa)

Unemploy.by duration: persons unempl. 27 wks+ (thous, sa)

Housing starts: nonfarm(1947-

58); total farm\&nonfarm(1959-)

(thous., sa)

Housing authorized: total new priv housing units (thous., saar)

HStarts: NE

HStarts: MW
Housing starts:northeast (thous.u.), sa

Housing starts:midwest (thous.u.), sa 


\begin{tabular}{|c|c|c|c|c|}
\hline HStarts: South & HSSOU & 4 & 1 & $\begin{array}{l}\text { Housing } \\
\text { starts:south } \\
\text { (thous.u.), sa }\end{array}$ \\
\hline HStarts: West & HSWST & 4 & 1 & $\begin{array}{c}\text { Housing } \\
\text { starts:west } \\
\text { (thous.u.), sa }\end{array}$ \\
\hline PMI & PMI & 1 & 1 & $\begin{array}{l}\text { Purchasing } \\
\text { managers' } \\
\text { index (sa) }\end{array}$ \\
\hline $\begin{array}{l}\text { NAPM new } \\
\text { ordrs }\end{array}$ & PMNO & 1 & 1 & $\begin{array}{l}\text { Napm new } \\
\text { orders index } \\
\text { (percent) }\end{array}$ \\
\hline $\begin{array}{l}\text { NAPM vendor } \\
\text { del }\end{array}$ & PMDEL & 1 & 1 & $\begin{array}{l}\text { Napm vendor } \\
\text { deliveries } \\
\text { index (percent) }\end{array}$ \\
\hline NAPM Invent & PMNV & 1 & 1 & $\begin{array}{c}\text { Napm } \\
\text { inventories } \\
\text { index (percent) }\end{array}$ \\
\hline $\begin{array}{l}\text { Orders } \\
\text { (ConsGoods) }\end{array}$ & MOCMQ & 5 & 1 & $\begin{array}{c}\text { New orders } \\
\text { (net) - } \\
\text { consumer } \\
\text { goods \& } \\
\text { materials, 1996 } \\
\text { dollars (bci) }\end{array}$ \\
\hline $\begin{array}{l}\text { Orders } \\
\text { (NDCapGoods) }\end{array}$ & MSONDQ & 5 & 1 & $\begin{array}{c}\text { New orders, } \\
\text { nondefense } \\
\text { capital goods, } \\
\text { in } 1996 \\
\text { dollars (bci) }\end{array}$ \\
\hline PGDP & GDP272A & 6 & 0 & $\begin{array}{c}\text { Gross domestic } \\
\text { product } \\
\text { price index }\end{array}$ \\
\hline PCED & GDP273A & 6 & 0 & $\begin{array}{l}\text { Personal } \\
\text { consumption } \\
\text { expenditures } \\
\text { price index }\end{array}$ \\
\hline
\end{tabular}




\begin{tabular}{|c|c|c|c|c|}
\hline CPI-All & CPIAUCSL & 6 & 0 & $\begin{array}{l}\text { CPI all items } \\
\text { (sa) fred }\end{array}$ \\
\hline PCED-Core & PCEPILFE & 6 & 0 & $\begin{array}{c}\text { PCE price } \\
\text { index less food } \\
\text { and energy } \\
\text { (sa) (FRED) }\end{array}$ \\
\hline CPI-Core & CPILFESL & 6 & 0 & $\begin{array}{l}\text { CPI less food } \\
\text { and energy } \\
\text { (sa) (FRED) }\end{array}$ \\
\hline PCED-Dur & GDP274A & 6 & 0 & $\begin{array}{l}\text { Durable goods } \\
\text { price index }\end{array}$ \\
\hline PCED-motorveh & GDP274 1 & 6 & 1 & $\begin{array}{l}\text { Motor vehicles } \\
\text { and parts } \\
\text { price index }\end{array}$ \\
\hline PCED-hhequip & GDP274 2 & 6 & 1 & $\begin{array}{l}\text { Furniture and } \\
\text { household } \\
\text { equipment } \\
\text { price index }\end{array}$ \\
\hline PCED-oth dur & GDP274 3 & 6 & 1 & $\begin{array}{l}\text { Other durable } \\
\text { price index }\end{array}$ \\
\hline PCED-nondur & GDP275A & 6 & 0 & $\begin{array}{l}\text { Nondurable } \\
\text { goods } \\
\text { price index }\end{array}$ \\
\hline PCED-food & GDP275 1 & 6 & 1 & $\begin{array}{l}\text { Food price } \\
\text { index }\end{array}$ \\
\hline PCED-clothing & GDP275 2 & 6 & 1 & $\begin{array}{l}\text { Clothing } \\
\text { and shoes } \\
\text { price index }\end{array}$ \\
\hline PCED-energy & GDP275 3 & 6 & 1 & $\begin{array}{l}\text { Gasoline, fuel } \\
\text { oil, and other } \\
\text { energy goods } \\
\text { price index }\end{array}$ \\
\hline $\begin{array}{l}\text { PCED-oth } \\
\text { nondur }\end{array}$ & GDP275 4 & 6 & 1 & $\begin{array}{c}\text { Other } \\
\text { nondorable } \\
\text { price index }\end{array}$ \\
\hline
\end{tabular}




\begin{tabular}{|c|c|c|c|c|}
\hline PCED-services & GDP276A & 6 & 0 & $\begin{array}{l}\text { Services } \\
\text { price index }\end{array}$ \\
\hline PCED-housing & GDP276 1 & 6 & 1 & $\begin{array}{l}\text { Housing } \\
\text { price index }\end{array}$ \\
\hline PCED-hhops & GDP276 2 & 6 & 0 & $\begin{array}{l}\text { Household } \\
\text { operation } \\
\text { price index }\end{array}$ \\
\hline $\begin{array}{l}\text { PCED-elect \& } \\
\text { gas }\end{array}$ & GDP276 3 & 6 & 1 & $\begin{array}{l}\text { Electricity and } \\
\text { gas price index }\end{array}$ \\
\hline $\begin{array}{l}\text { PCED-oth } \\
\text { hhops }\end{array}$ & GDP276 4 & 6 & 1 & $\begin{array}{l}\text { Other } \\
\text { household } \\
\text { operation } \\
\text { price index }\end{array}$ \\
\hline PCED-transport & GDP276 5 & 6 & 1 & $\begin{array}{l}\text { Transportation } \\
\text { price index }\end{array}$ \\
\hline PCED-medical & GDP276 6 & 6 & 1 & $\begin{array}{l}\text { Medical care } \\
\text { price index }\end{array}$ \\
\hline $\begin{array}{l}\text { PCED- } \\
\text { recreation }\end{array}$ & GDP276 7 & 6 & 1 & $\begin{array}{l}\text { Recreation } \\
\text { price index }\end{array}$ \\
\hline PCED-oth serv & GDP276 8 & 6 & 1 & $\begin{array}{l}\text { Other service } \\
\text { price index }\end{array}$ \\
\hline PGPDI & GDP277A & 6 & 0 & $\begin{array}{l}\text { Gross private } \\
\text { domestic } \\
\text { investment } \\
\text { price index }\end{array}$ \\
\hline PFI & GDP278A & 6 & 0 & $\begin{array}{l}\text { Fixed } \\
\text { investment } \\
\text { price index }\end{array}$ \\
\hline PFI-nonres & GDP279A & 6 & 0 & $\begin{array}{c}\text { Nonresidential } \\
\text { price index }\end{array}$ \\
\hline $\begin{array}{l}\text { PFI-nonres } \\
\text { struc }\end{array}$ & GDP280A & 6 & 1 & Structures \\
\hline $\begin{array}{l}\text { PFI-nonres } \\
\text { equip }\end{array}$ & GDP281A & 6 & 1 & $\begin{array}{l}\text { Equipment } \\
\text { and software } \\
\text { price index }\end{array}$ \\
\hline
\end{tabular}




\begin{tabular}{|c|c|c|c|c|}
\hline PFI-resdidential & GDP282A & 6 & 1 & $\begin{array}{l}\text { Residential } \\
\text { price index }\end{array}$ \\
\hline PEXP & GDP284A & 6 & 1 & $\begin{array}{l}\text { Exports } \\
\text { price index }\end{array}$ \\
\hline PIMP & GDP285A & 6 & 1 & $\begin{array}{l}\text { Imports } \\
\text { price index }\end{array}$ \\
\hline PGOV & GDP286A & 6 & 0 & $\begin{array}{c}\text { Government } \\
\text { consumption } \\
\text { expenditures } \\
\text { and gross } \\
\text { investment } \\
\text { price index }\end{array}$ \\
\hline PGOV-Federal & GDP287A & 6 & 1 & $\begin{array}{c}\text { Federal } \\
\text { price index }\end{array}$ \\
\hline PGOV-St \& loc & GDP288A & 6 & 1 & $\begin{array}{l}\text { State and local } \\
\text { price index }\end{array}$ \\
\hline $\begin{array}{l}\text { Com: spot price } \\
\text { (real) }\end{array}$ & PSCCOMR & 5 & 1 & $\begin{array}{c}\text { Real spot } \\
\text { market price } \\
\text { index:bls \& crb: } \\
\text { all commodities } \\
\text { (1967 = 100) } \\
\text { (psccom/ } \\
\text { PCEpilfe) }\end{array}$ \\
\hline OilPrice (Real) & PW561R & 5 & 1 & $\begin{array}{l}\text { Ppi crude } \\
\text { (relative to core } \\
\text { PCE) (pw561/ } \\
\text { PCEpilfe) }\end{array}$ \\
\hline $\begin{array}{l}\text { NAPM com } \\
\text { price }\end{array}$ & PMCP & 1 & 1 & $\begin{array}{l}\text { Napm } \\
\text { commodity } \\
\text { prices index } \\
\text { (percent) }\end{array}$ \\
\hline $\begin{array}{l}\text { Real AHE: } \\
\text { goods }\end{array}$ & CES275R & 5 & 0 & $\begin{array}{l}\text { Real avg hrly } \\
\text { earnings, prod } \\
\text { wrkrs, nonfarm } \\
\text { - goods- } \\
\text { producing } \\
\text { (ces275/pi071) }\end{array}$ \\
\hline
\end{tabular}




\begin{tabular}{|c|c|c|c|c|}
\hline Real AHE: const & CES277R & 5 & 1 & $\begin{array}{l}\text { Real avg hrly } \\
\text { earnings, prod } \\
\text { wrkrs, nonfarm } \\
\text { - construction } \\
\text { (ces277/pi071) }\end{array}$ \\
\hline Real AHE: mfg & CES278 R & 5 & 1 & $\begin{array}{l}\text { Real avg hrly } \\
\text { earnings, } \\
\text { prod wrkrs, } \\
\text { nonfarm - mfg } \\
\text { (ces278/pi071) }\end{array}$ \\
\hline Labor Prod & LBOUT & 5 & 1 & $\begin{array}{l}\text { Output per } \\
\text { hour all } \\
\text { persons: } \\
\text { business } \\
\text { sec }(1982 \\
=100, \text { sa) }\end{array}$ \\
\hline $\begin{array}{l}\text { Real Comp/ } \\
\text { Hour }\end{array}$ & LBPUR7 & 5 & 1 & $\begin{array}{c}\text { Real } \\
\text { compensation } \\
\text { per hour, } \\
\text { employees:nonfarm } \\
\text { business ( } 82 \\
=100, \mathrm{sa})\end{array}$ \\
\hline Unit Labor Cost & LBLCPU & 5 & 1 & $\begin{array}{l}\text { Unit labor } \\
\text { cost: nonfarm } \\
\text { business } \\
\text { sec }(1982 \\
=100, \text { sa })\end{array}$ \\
\hline FedFunds & FYFF & 2 & 1 & $\begin{array}{l}\text { Interest rate: } \\
\text { federal funds } \\
\text { (effective) } \\
\text { (\% per } \\
\text { annum, nsa) }\end{array}$ \\
\hline 3 mo T-bill & FYGM3 & 2 & 1 & $\begin{array}{l}\text { Interest rate: } \\
\text { u.s.treasury } \\
\text { bills, sec mkt, } \\
\text { 3-mo.(\% per } \\
\text { ann, nsa) }\end{array}$ \\
\hline
\end{tabular}




\begin{tabular}{|c|c|c|c|c|}
\hline 6 mo T-bill & FYGM6 & 2 & 0 & $\begin{array}{l}\text { Interest rate: } \\
\text { u.s.treasury } \\
\text { bills, sec mkt, } \\
\text { 6-mo.(\% per } \\
\text { ann, nsa) }\end{array}$ \\
\hline 1 yr T-bond & FYGT1 & 2 & 1 & $\begin{array}{c}\text { Interest rate: } \\
\text { u.s.treasury } \\
\text { const } \\
\text { maturities, } \\
\text { 1-yr.(\% per } \\
\text { ann, nsa) }\end{array}$ \\
\hline 5 yr T-bond & FYGT5 & 2 & 0 & $\begin{array}{c}\text { Interest rate: } \\
\text { u.s.treasury } \\
\text { const } \\
\text { maturities, } \\
\text { 5-yr.(\% per } \\
\text { ann, nsa) }\end{array}$ \\
\hline $10 \mathrm{yr}$ T-bond & FYGT10 & 2 & 1 & $\begin{array}{c}\text { Interest rate: } \\
\text { u.s.treasury } \\
\text { const } \\
\text { maturities, } \\
\text { 10-yr. } \% \text { per } \\
\text { ann, nsa) }\end{array}$ \\
\hline Aaabond & FYAAAC & 2 & 0 & $\begin{array}{c}\text { Bond yield: } \\
\text { moody's aaa } \\
\text { corporate (\% } \\
\text { per annum) }\end{array}$ \\
\hline Baa bond & FYBAAC & 2 & 0 & $\begin{array}{c}\text { Bond yield: } \\
\text { moody's baa } \\
\text { corporate (\% } \\
\text { per annum) }\end{array}$ \\
\hline fygm6-fygm3 & SFYGM6 & 1 & 1 & fygm6-fygm3 \\
\hline fygt1-fygm3 & SFYGT1 & 1 & 1 & fygt1-fygm3 \\
\hline fygt10-fygm3 & SFYGT10 & 1 & 1 & fygt10-fygm3 \\
\hline fyaaac-fygt10 & SFYAAAC & 1 & 1 & fyaaac-fygt10 \\
\hline fybaac-fygt10 & SFYBAAC & 1 & 1 & fybaac-fygt 10 \\
\hline
\end{tabular}


M1

MZM

M2

MB

Reserves tot

Reserves

nonbor

FMRNBA

BUSLOANS

Bus loans

Cons credit

FM1

MZMSL

FMFBA

FMRRA
6

6

6

6

1

1

1

1

Money stock:

m1 (curr, trav.cks, dem dep, other ck'able dep) (bil\$, sa)

Mzm (sa)

frb st. Louis

Money stock:m2

(m1+o'nite rps, euro\$, g/p\&b/d $\mathrm{mmmfs} \& s a v \& s m$

time dep

(bil\$, sa)

Monetary base, adj for reserve requirement changes (mil\$, sa)

1 Depository inst reserves:total, adj for reserve req chgs (mil\$, sa)

1 Depository inst reserves:nonborrowed, adj res req chgs (mil\$, sa)

Commercial and industrial loans at all commercial banks (FRED) billions \$ (sa)

\section{Consumer credit outstanding -}


nonrevolving

(g19)

Ex rate: avg

Ex rate: Switz

EXRSW

EXRJAN

Ex rate: Japan

Ex rate: UK

EX rate:

Canada

EXRCAN

5

FSPCOM

5

FSPIN

S\&P: indust

5

2

5

5

5
1

United

States; effective exchange rate(merm) (index no.)

1

Foreign

exchange rate:

Switzerland

(Swiss franc

per u.s. \$)

1

Foreign

exchange rate:

Japan (yen

per u.s. \$)

1

Foreign

exchange

rate: United

Kingdom (cents

per pound)

1

Foreign

exchange

rate: Canada

(Canadian \$

per u.s. \$)

S\&P's common

stock price

index:

composite

$(1941-43=10)$

S\&P's common

stock price index:

industrials

$(1941-43=10)$

S\&P'S

composite 
common stock:

dividend yield

(\% per annum)

S\&P PE ratio

FSPXE

2

DJIA

FSDJ

5

HHSNTN

Consumer

expect
1

S\&P's

composite

common stock:

price-earnings

ratio (\%, nsa)

1

Common stock prices: Dow Jones industrial

average

U. of Mich. index of

consumer

expectations

(bcd-83)

(p. 200$)($ p. 201$)($ (p. 202$)$

\section{(p. 203 )}

\section{Code}

1

2

3

4

5

6

\section{Transformation $\left(X_{\text {it }}\right)$}

$X_{i t}=Y_{i t}$

$X_{i t}=\Delta Y_{i t}$

$X_{i t}=\Delta 2 Y_{i t}$

$X_{i t}=\ln Y_{i t}$

$X_{i t}=\Delta \ln Y_{i t}$

$X_{i t}=\Delta^{2} \ln Y_{i t}$

\section{$h$-quarter ahead variable}

$X_{i t}^{(h)}$

$X_{i t}^{(h)}=Y_{i t+h}$

$X_{i t}^{(h)}=Y_{i t+h}-Y_{i t}$

$X_{i t}^{(h)}=h^{-1} \sum_{j=1}^{h} \Delta Y_{i, t+h-j}-\Delta Y_{i t}$

$X_{i t}^{(h)}=\operatorname{In} Y_{i t+h}$

$X_{i t}^{(h)}=\operatorname{In} Y_{i t+h}-\operatorname{In} Y_{i t}$

$X_{i t}^{(h)}=h^{-1} \sum_{j=1}^{h} \Delta \operatorname{In} Y_{i, t+h-j}-\Delta \operatorname{In} Y_{i t}$

(p. 204 ) References

Bibliography references: 
Bai, J. and Ng, S. (2002). Determining the number of factors in approximate factor models. Econometrica, 70, 191-221.

- - - (2006). Confidence intervals for diffusion index forecasts and inference for factor-augmented regressions. Econometrica, 74, 1133-1150

Banerjee, A., Marcellino, M. and Masten, I. (2007). Forecasting macroeconomic variables using diffusion indexes in short samples with structural change, forthcoming in Forecasting in the Presence of Structural Breaks and Model Uncertainty, edited by D. Rapach and M. Wohar, Elsevier.

Chamberlain, G. and Rothschild, M. (1983). Arbitrage factor stucture, and mean-variance analysis of large asset markets. Econometrica, 51, 12811304.

Clements, M. P. and Hendry, D. F. (1999). Forecasting Non-stationary Economic Time Series. Cambridge, Mass: MIT Press.

- - - (2002). Modeling methodology and forecast failure. Econometrics Journal, 5, 319-344.

Del Negro, M. and Otrok, C. (2008). Dynamic factor models with time-varying parameters: Measuring changes in international business cycles. Federal Reserve Bank of New York Staff Report No. 326.

Forni, M., Hallin, M., Lippi, M. and Reichlin, L. (2000). The generalized factor model: Identification and estimation, The Review of Economics and Statistics, 82, 540-554.

Geweke, J. (1977). The dynamic factor analysis of economic time series. In Aigner, D. J. and Goldberger, A. S. (eds.) Latent Variables in Socio-Economic Models. Amsterdam: North-Holland.

Hendry, D. F. (2005). Unpredictability and the foundations of economic forecasting. Nuffield Economics Working Paper 2004-W15.

- - and Clements, M. P. (2002). Pooling of forecasts. Econometrics Journal, 5, $1-26$.

- - and Mizon, G. E. (2005). Forecasting in the presence of structural breaks and policy regime shifts. Ch. 20 in Stock, J. H. and Andrews, D. W. K. (eds.), Identification and Inference for Econometric Models: Essays in Honor of Thomas J. Rothenberg, pp. 481-502. Cambridge: Cambridge University Press. 
Kim, C. -J. and Nelson, C. R. (1999). Has the U.S. economy become more stable ? A Bayesian approach based on a Markov-switching model of the business cycle. The Review of Economics and Statistics, 81, 608-616.

McConnell, M. M. and Perez-Quiros, G. (2000). Output fluctuations in the United States: What has changed since the early 1980 's. American Economic Review, 90(5), 1464- 1476.

Newey, W. K. and West, K. D. (1987). A simple positive semi-definite, heteroskedasticity and autocorrelation consistent covariance matrix. Econometrica, 55, 703-708.

Sargent, T. J. (1989). Two models of measurements and the investment accelerator. The Journal of Political Economy, 97, 251-287.

- - and Sims, C. A. (1977). Business cycle modeling without pretending to have too much a-priori economic theory. In Sims, C. et al., (eds.), New Methods in Business Cycle Research. Minneapolis: Federal Reserve Bank of Minneapolis.

Stock, J. H. and Watson, M. W. (1998). Diffusion indexes manuscript, Harvard University.

(p. 205 ) - - - (2002a). Macroeconomic forecasting using diffusion indexes. Journal of Business and Economic Statistics, 20, 147-162.

- - - - (2002b). Forecasting using principal components from a large number of predictors. Journal of the American Statistical Association, 97, 1167-1179.

_- - - (2005). Implications of dynamic factor models for VAR analysis, Manuscript.

- - - (2006). Forecasting with many predictors, Ch. 6 in Elliott, G., Granger, C. W. J. and Timmermann, A. (eds.), Handbook of Economic Forecasting, pp. 515-554, Elsevier.

- - - (2007). Why has inflation become harder to forecast ?. Journal of Money, Credit, and Banking, 39, 3-34.

Notes:

* This research was funded in part by NSF grant SBR-0617811. 


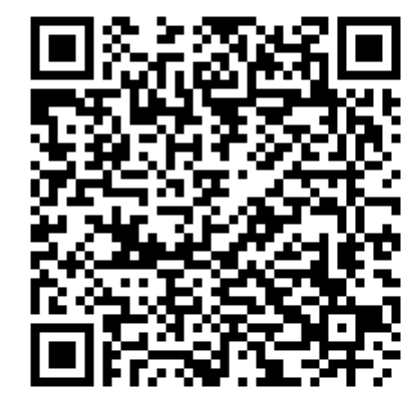

Page 57 of 57

Forecasting in Dynamic Factor Models Subject to Structural Instability*

PRINTED FROM OXFORD SCHOLARSHIP ONLINE (www.oxfordscholarship.com). (c) Copyright Oxford University Press, 2012.

All Rights Reserved. Under the terms of the licence agreement, an individual user may print out a PDF of a single chapter of a

monograph in OSO for personal use (for details see http://www.oxfordscholarship.com/page/privacy-policy). Subscriber: Harvard

University Library; date: 06 August 2012 